\title{
Ethylene, a key factor in the regulation of seed dormancy
}

\section{Françoise Corbineau*, Qiong Xia, Christophe Bailly and Hayat El-Maarouf-Bouteau}

Biologie des Semences (Seed Biology), UMR7622 CNRS-UPMC, Sorbonne Universités - Université Pierre et Marie Curie-Paris, Paris, France

\section{Edited by:}

Domenico De Martinis, Italian

National Agency for New

Technologies, Energy and Sustainable

Economic Development, Italy

\section{Reviewed by:}

Wendy A. Peer, University of

Maryland, USA

Luciano Freschi, University of São

Paulo, Brazil

\section{*Correspondence:}

Françoise Corbineau, Biologie des Semences (Seed Biology), Laboratoire de Biologie du Développement, Sorbonne Universités - Université Pierre et Marie Curie-Paris, UMR 7622, Bat C2, Boîte Courrier 24, 4 Place Jussieu, 75005 Paris, France e-mail: francoise.corbineau@upmc.fr
Ethylene is an important component of the gaseous environment, and regulates numerous plant developmental processes including seed germination and seedling establishment. Dormancy, the inability to germinate in apparently favorable conditions, has been demonstrated to be regulated by the hormonal balance between abscisic acid (ABA) and gibberellins (GAs). Ethylene plays a key role in dormancy release in numerous species, the effective concentrations allowing the germination of dormant seeds ranging between 0.1 and $200 \mu \mathrm{L} \mathrm{L}^{-1}$. Studies using inhibitors of ethylene biosynthesis or of ethylene action and analysis of mutant lines altered in genes involved in the ethylene signaling pathway (etr1, ein2, ain 1, etr1, and erf1) demonstrate the involvement of ethylene in the regulation of germination and dormancy. Ethylene counteracts $A B A$ effects through a regulation of $A B A$ metabolism and signaling pathways. Moreover, ethylene insensitive mutants in Arabidopsis are more sensitive to ABA and the seeds are more dormant. Numerous data also show an interaction between ABA, GAs and ethylene metabolism and signaling pathways. It has been increasingly demonstrated that reactive oxygen species (ROS) may play a significant role in the regulation of seed germination interacting with hormonal signaling pathways. In the present review the responsiveness of seeds to ethylene will be described, and the key role of ethylene in the regulation of seed dormancy via a crosstalk between hormones and other signals will be discussed.

Keywords: abscisic acid, dormancy, ethylene, gibberellins, reactive oxygen species, seed germination

\section{INTRODUCTION}

In soil, seeds are exposed to various environmental factors including temperature, moisture, oxygen and light, which regulate seed germination, and subsequent seedling growth. Phase I of the germination process is initiated by imbibition, which is required to activate the respiratory metabolism, and transcriptional and translational activities. In phase II called germination sensu stricto, water uptake ceases and reserve mobilization starts. Phase III is characterized by radicle protrusion (Bewley and Black, 1994; Bewley, 1997; Nonogaki et al., 2010; Weitbrecht et al., 2011). Germination requires specific temperatures, oxygen levels and light, the exact proportions being species specific. However, the seeds of species (or even within species) do not germinate, or do so with difficulty, even when incubated under apparently favorable conditions; these are considered as dormant and cannot germinate in the same conditions (i.e., water, air, temperature) under which non-dormant seeds do (Bewley and Black, 1994; Corbineau and Côme, 1995; Bewley, 1997). Dormancy is a heritable trait, but its intensity at harvest and its maintenance after harvest is highly modulated by the environmental conditions throughout seed development and ripening on the plant, and during seed storage (Bewley, 1997). Factors inhibiting germination can reside within the embryo itself (embryo dormancy) or can result from an inhibitory action of the covering structures (seed coat imposed dormancy; Bewley and Black, 1994; Hilhorst, 2007). Primary dormancy sets during seed development, but a secondary dormancy can develop in mature seeds with some degree of primary dormancy or in non-dormant seeds in response to unfavorable conditions for germination (Hilhorst, 2007; Hilhorst et al., 2010).

The involvement of the hormonal balance between abscisic acid (ABA) and gibberellins (GAs) in the regulation of seed germination and dormancy in response to environmental signals is well documented and discussed in recent reviews (Finkelstein et al., 2008; Nambara et al., 2010; Nonogaki et al., 2010; Weitbrecht etal., 2011; Graeber et al., 2012; Rajjou et al., 2012; Arc et al., 2013; Miransari and Smith, 2014). ABA is well known to play a crucial role in induction of dormancy in the developing seeds and in maintenance of dormancy during seed imbibition, while GAs are involved in dormancy release and/or germination (Finkelstein et al., 2008; Cutler et al., 2010; Nambara et al., 2010; Miransari and Smith, 2014). In addition to GAs and ABA, other hormones (ethylene, jasmonates, auxins) also play a role in the control of seed germination (Linkies and Leubner-Metzger, 2012; Arc etal., 2013; Miransari and Smith, 2014). Ethylene $\left(\mathrm{C}_{2} \mathrm{H}_{4}\right)$ in particular regulates germination and dormancy of numerous species via a complex hormonal signaling network (Matilla, 2000; Brady and McCourt, 2003; Feurtado and Kermode, 2007; Matilla and Matilla-Vazquez, 2008; Arc et al., 2013).

The role of reactive oxygen species (ROS) in seed biology has progressively emerged and evolved this last decade. Originally considered as harmful compounds, causing deleterious reactions toward a wide range of biomolecules and thus to seeds, ROS are now widely acknowledged as signaling compounds regulating the germination process through an 
hormonal network (Bailly et al., 2008; Diaz-Vivancos et al., 2013; El-Maarouf-Bouteau et al., 2014).

In this review, we describe how ethylene interacts with other plant hormones in regulation of germination and dormancy, concentrating on its interactions with ABA, GAs, and ROS.

\section{ETHYLENE BIOSYNTHESIS DURING GERMINATION}

Ethylene production by seeds begins immediately after the onset of imbibition and increases with time of germination. There is, however, a peak in ethylene emission concomitant with the radicle protrusion through the seed coat (Ketring and Morgan, 1969; Fu and Yang, 1983; Satoh and Esashi, 1983; Gallardo et al., 1991; Gorecki etal., 1991; Siriwitayawan et al., 2003; El-Maarouf-Bouteau et al., 2014). Seed ethylene production is species dependent (Kepczynski and Kepczynska, 1997; Matilla, 2000), but is generally below levels detectable by gas chromatography during imbibition. Using a high sensitivity laser photo acoustic spectroscopy (Cristescu et al., 2008), El-Maarouf-Bouteau et al. (2014) have confirmed the occurrence of an ethylene peak at the end of the germination process in sunflower (Helianthus annuus) seeds. Interestingly, a close relationship between the ability to produce ethylene and seed vigor has been reported in various species including rape (Brassica napus; Takayanagi and Harrington, 1971), cotton (Gossypium spp.; Ketring et al., 1974), peanut (Arachis hypogaea; Ketring et al., 1974), cocklebur (Xanthium pennsylvanicum; Gorecki et al., 1991), snap bean (Phaseolus vulgaris; Samimy and Taylor, 1983), sunflower (Chonowski et al., 1997) and pea (Pisum sativum; Gorecki et al., 1991), and 1-aminocyclopropane 1-carboxylic acid (ACC)-dependent $\mathrm{C}_{2} \mathrm{H}_{4}$ production was proposed as a marker of seed quality (Khan, 1994; Corbineau, 2012).

The pathway of ethylene biosynthesis in seeds is the same as that described for other plant organs, in which $S$-adenosylmethionine ( $S$-AdoMet) and ACC are the main intermediates (Yang and Hoffman, 1984; Wang et al., 2002; Rzewuski and Sauter, 2008; Figure 1). S-AdoMet synthesized from methionine by the $S$-AdoMet synthetase (or SAM synthetase), is converted to ACC, the direct precursor of ethylene, by ACC synthase ( $S$-adenosyl-L-methionine methylthioadenosine-lyase, ACS). The by-product $5^{\prime}$-methylthioadenosine (MTA) is recycled back to methionine through the Yang Cycle (Yang and Hoffman, 1984; Kende, 1993). S-AdoMet is also the precursor of the biosynthesis of polyamines, which can also play a role in seed germination (Matilla, 1996). Ethylene production results from the oxidation of ACC by ACC oxidase (ACO), which also generates $\mathrm{CO}_{2}$ and hydrogen cyanide (HCN; Figure 1). Autocatalytic synthesis of ethylene via induction of $A C C$ and $A C O$ transcription is well known in fruit ripening (Lin et al., 2009), ethylene also regulates ACO expression in pea (Petruzzelli et al., 2000, 2003), beechnut (Fagus sylvatica; Calvo et al., 2004b), and turnip (Brassica rapa; Puga-Hermida et al., 2003). In contrast, ethylene or ACC does not affect the abundance of ACO transcript in sugar beet (Beta vulgaris; Hermann etal., 2007) and, expression of SoACS7 in Sisymbrium officinale and PsAC1 in pea (Petruzzelli et al., 2000, 2003; Iglesias-Fernandez and Matilla, 2010).

Increased ethylene production during germination is associated with an increase in ACO activity, as well as a progressive accumulation of ACS and ACO transcripts (Gomez-Jimenez et al., 1998; Matilla and Matilla-Vazquez, 2008; Linkies et al., 2009; Iglesias-Fernandez and Matilla, 2010; Linkies and Leubner-Metzger, 2012). Although ACS is considered to be a key enzyme in the regulation of ethylene production in most plant responses to abiotic and biotic stresses (Wang et al., 2002), it was demonstrated in seeds that ACO activity plays a fundamental role during germination (Matilla and Matilla-Vazquez, 2008; Linkies and Leubner-Metzger, 2012). Both ACS and ACO are encoded by a multigene family, and the regulation of particular ACS and ACO genes differ among each other (Wang et al., 2002, 2005; Yamagami et al., 2003). In both Arabidopsis and cress (Lepidium sativum), ACO1 and ACO2 have been demonstrated to be the major ACOs involved in ethylene synthesis (Linkies et al., 2009; Linkies and Leubner-Metzger, 2012), and the correlation between the abundance of ACO transcripts and the ACO activity suggests its regulation at a transcriptional level during germination.

Ethylene is involved in various developmental processes and responses to biotic and abiotic stresses in plants (Bleecker and Kende, 2000; Wang etal., 2002). The key components in its signaling pathway have been identified using a molecular dissection of ethylene responsiveness in Arabidopsis (Wang etal., 2002; Stepanova and Alonso, 2009; Yoo et al., 2009). Five membrane-localized ethylene receptors, ethylene resistant 1 (ETR1), ETR2, ethylene response sensor 1 (ERS1), ERS2, and ethylene insensitive 4 (EIN4) exist in Arabidopsis (Wang et al., 2002). Among them, ETR1 and ERS1 contain three transmembrane domains in the $\mathrm{N}$-terminus and a histidine kinase domain in the C-terminus, when ETR2, EIN4, and ERS2 present four transmembrane regions and a serine-threonine kinase domain in the C-terminus (Wang etal., 2006; Kendrick and Chang, 2008). Binding of ethylene to its receptors results in inactivation of CTR1 (constitutive triple response 1) protein kinase, which in turn activates the kinase cascade controlling EIN2 and its transcription factors in the nucleus. These, such as EIN3, EILs, ethylene response element binding proteins (EREBPs)/ethylene responsive factors (ERFs) activate the transcription of ethylene response genes (Wang etal., 2002; Liu etal., 2004; Hall etal., 2007; Rzewuski and Sauter, 2008; Yoo et al., 2008, 2009; Stepanova and Alonso, 2009; Figure 1). Recently, it was demonstrated that EIN2 is phosphorylated by CTR1 kinase in the absence of ethylene, and that EIN2 protein level is regulated through its degradation by the proteasome (Qiao et al., 2009, 2012; Ju et al., 2012).

\section{SEED RESPONSIVENESS TO EXOGENOUS ETHYLENE}

Exogenous ethylene or ethephon, an ethylene releasing compound, improves germination in numerous species (Esashi, 1991; Corbineau and Côme, 1995; Kepczynski and Kepczynska, 1997; Matilla, 2000; Matilla and Matilla-Vazquez, 2008; Arc et al., 2013). It stimulates germination of non-dormant seeds incubated in non-optimal environmental conditions such as too high temperatures (Rao et al., 1975; Abeles, 1986; Gallardo et al., 1991), osmotic stress (Negm and Smith, 1978; Kepczynski, 1986; Khan et al., 2009), hypoxia (Esashi et al., 1989; Corbineau and Côme, 1992), and salinity (Zapata et al., 2003; Wang et al., 2011; Lin etal., 2013; Silva etal., 2014). It can also break primary and 


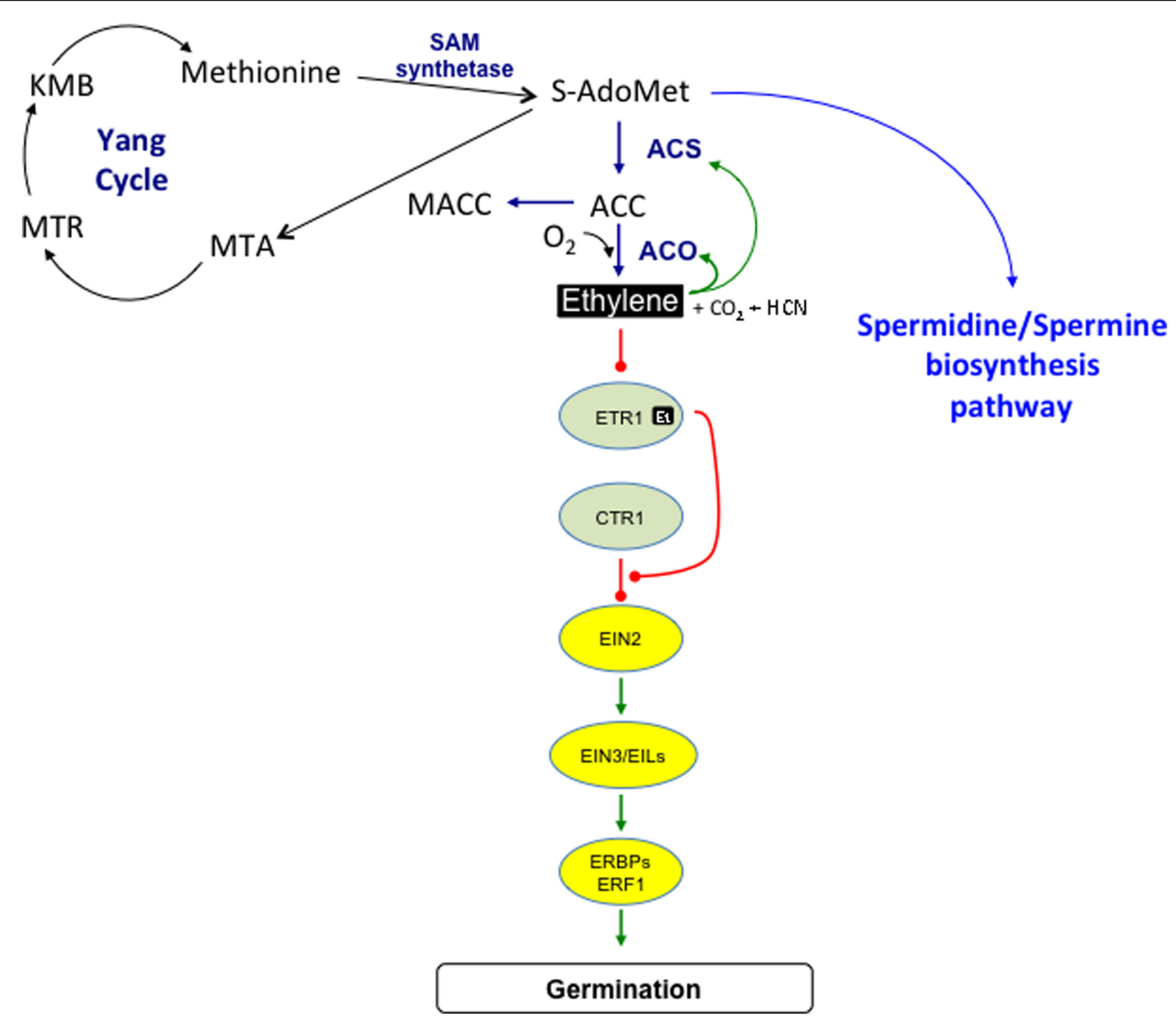

FIGURE 1 | Ethylene biosynthesis and signaling pathways. S-adenosyl methionine ( $S$-AdoMet) is synthesized from methionine by the SAM synthetase, it is then converted to 1-aminocyclopropane-1-carboxylic acid (ACC) by the ACC synthase (ACS), 5-methylthioadenosine (MTA) being a by-product. MTA is recycled to methionine through the Yang Cycle by successive enzymatic reactions involving different intermediates among which 5-methylthioribose (MTR) and 2-keto-4-methylthiobutyrate (KMB). $S$-AdoMet is also the precursor of the spermidine/spermine biosynthesis pathway. Ethylene production results from the ACC oxidation catalyzed by the ACC oxidase (ACO) that also generates carbon dioxide and cyanide. Malonylation of ACC to malonyl-ACC (MACC) reduces $\mathrm{ACC}$ content and consequently ethylene production.
Ethylene can stimulate its own biosynthesis, by improving ACC synthesis catalyzed by ACS, and conversion to ethylene by ACO. Ethylene binds to receptors (among which ethylene receptor 1, ETR1) located in the endoplasmic reticulum, which leads to the deactivation of the receptors that become able to recruit CTR1 (constitutive triple response). Release of CTR1 inhibition allows EIN2 to act as a positive regulator of ethylene signaling pathway. EIN2 acts upstream of nuclear transcription factors, such as EIN3 (ethylene insensitive), EILs (EIN3-like), ERBPs (ethylene responsive element binding protein), and ERFs (ethylene response factor). $\longrightarrow$ and $-\bullet$ arrows indicate positive and negative interactions between the different elements of the signaling cascade, respectively. secondary dormancy (Table 1). It breaks the embryo dormancy in apple (Malus domestica; Kepczynski et al., 1977; Sinska and Gladon, 1984; Sinska and Lewandowska, 1991) and beechnut (Calvo etal., 2004a), the dormancy of which is usually broken by chilling, and in sunflower (Corbineau et al., 1990), the dormancy of which is progressively alleviated during dry storage (after-ripening). It also promotes the germination of seeds exhibiting a seed coat imposed dormancy in various species such as cocklebur (Katoh and Esashi, 1975; Esashi et al., 1978), subterranean clover (Trifolium subterraneum; Esashi and Leopold, 1969), Rumex crispus (Taylorson, 1979), and Arabidopsis (Siriwitayawan et al., 2003). In particular, it can also overcome the secondary dormancy induced by high temperatures in lettuce (Lactuca sativa; Speer et al., 1974; Abeles, 1986), sunflower (Corbineau et al., 1988), Amaranthus caudatus (Kepczynski et al., 1996a) and Amaranthus paniculatus (Kepczynski and Kepczynska, 1993). In Rhus coriaria, a post-fire pioneer, low ethylene concentrations $\left(0.03-0.10 \mu \mathrm{L} \mathrm{L}^{-1}\right)$ released by wet ash stimulates germination (Ne'eman et al., 1999), although it does not improve that of many other species in which germination is smoke-induced (Brown and van Staden, 1997). Ethylene also improves germination of seeds from parasitic plants such as Striga asiatica, Striga lutea and Striga hermonthica (Egley and Dale, 1970; Bebawi and Eplee, 1986).

The stimulatory effect of ethylene is dose dependent, the hormone being efficient when applied at concentration ranging from 0.1 to $200 \mu \mathrm{L} \mathrm{L}^{-1}$ depending on the species, the depth of dormancy and the environmental conditions. Breaking of dormancy either during chilling in apple (Sinska, 1989) or dry storage in sunflower (Corbineau and Côme, 2003), Amaranthus retroflexus (Kepczynski and Sznigir, 2014) and Stylosanthes 
Table 1 | Plant species whose seed dormancy is broken by ethylene, ethephon, an ethylene releasing compound, or 1-aminocyclopropane1-carboxylic acid, the direct precursor of ethylene.

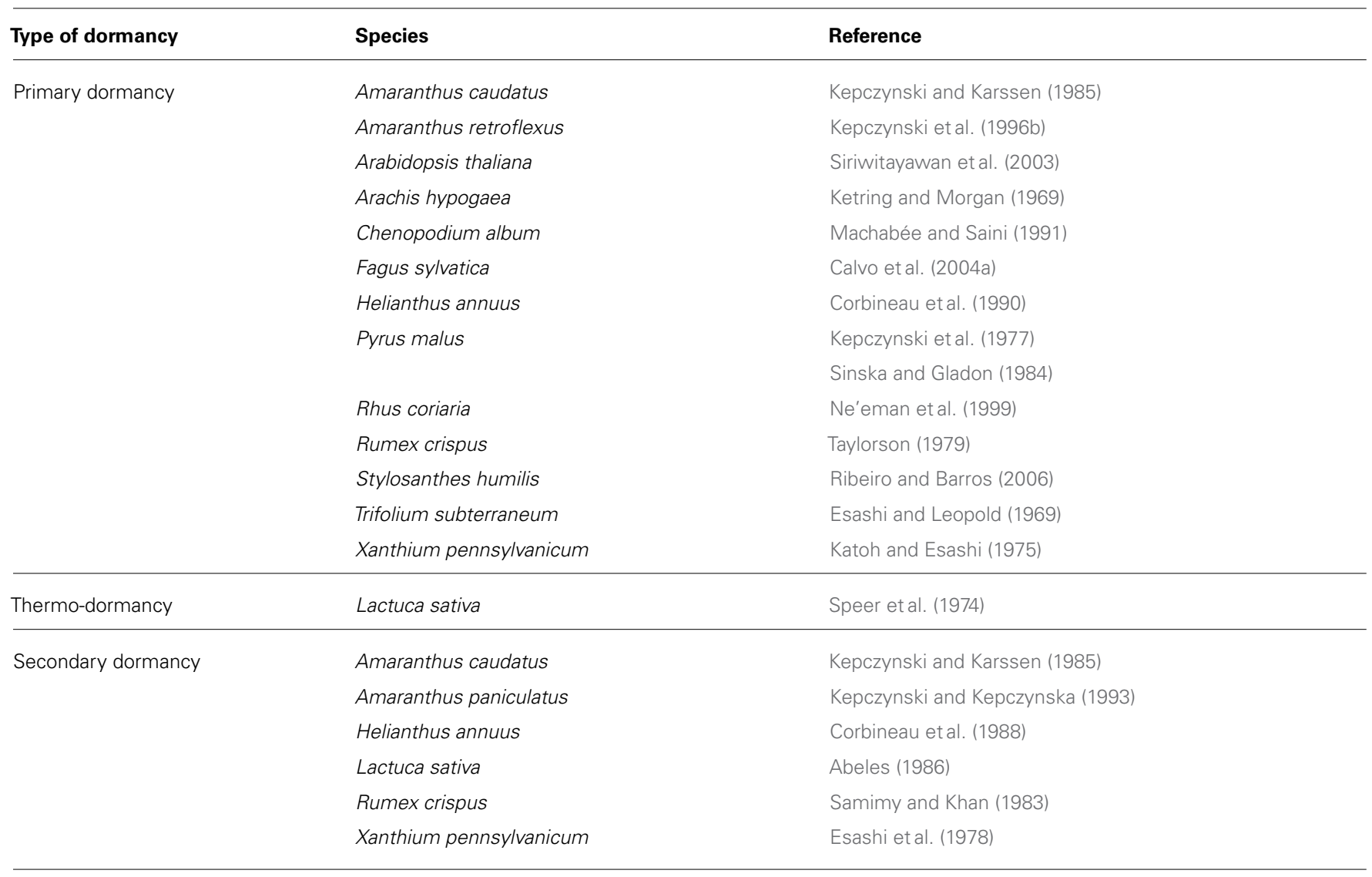

humilis (Ribeiro and Barros, 2006) is associated with an increasing sensitivity to ethylene. At harvest, dormant sunflower seeds require $50 \mu \mathrm{L} \mathrm{L}^{-1}$ ethylene in order to germinate at $15^{\circ} \mathrm{C}$, but only 10 and $3 \mu \mathrm{L} \mathrm{L}^{-1}$ after 8 and 15 weeks of dry-storage at $5^{\circ} \mathrm{C}$, respectively (Corbineau and Côme, 2003). In contrast, the responsiveness to the hormone decreases progressively during seed incubation under environmental conditions that induce a secondary dormancy (Negm et al., 1973; Speer et al., 1974; Esashi et al., 1978; Jones and Hall, 1984; Corbineau and Côme, 2003).

Although ethylene stimulates the germination of numerous light sensitive seeds, it does not overcome the light requirement in Amaranthus retroflexus (Schönbeck and Egley, 1981), celery (Apium graveolens; Thomas etal., 1975), lettuce (Burdett and Vidaver, 1971), and Spergula arvensis (Olatoye and Hall, 1973). Recently, Wilson et al. (2014b) demonstrate that loss of ETR1 reduces the inhibitory effect of far-red on the germination of Arabidopsis seeds through expression of genes involved in ABA and GAs metabolism. An epistasis analysis performed by the same authors also suggests that ETR1 may interact with phytochromes to control seed germination.

An additive or synergistic effect of $\mathrm{CO}_{2}$ and ethylene has also been demonstrated in seeds of peanut (Ketring and Morgan, 1972), Spergula arvensis (Jones and Hall, 1984), cocklebur (Katoh and
Esashi, 1975), and lettuce (Negm and Smith, 1978; Saini et al., 1986). In the case of cocklebur (Esashi et al., 1986) and sunflower (Corbineau et al., 1990) seeds, it was suggested that the improving effect of $\mathrm{CO}_{2}$ results from an enhancement of $\mathrm{C}_{2} \mathrm{H}_{4}$ biosynthesis, since it is suppressed in the presence of inhibitors of ethylene synthesis.

\section{INVOLVEMENT OF ETHYLENE IN SEED GERMINATION AND DORMANCY}

Numerous studies demonstrate that the ability to germinate correlates with ethylene production, suggesting that ethylene is involved in the regulation of seed germination and dormancy (reviewed in Kepczynski and Kepczynska, 1997; Matilla and Matilla-Vazquez, 2008; Arc etal., 2013). For example, induction of thermodormancy at high temperatures is associated with a reduced ethylene production in chickpea (Cicer arietinum; Gallardo et al., 1991), sunflower (Corbineau et al., 1988), and lettuce (Prusinski and Khan, 1990). This decrease in $\mathrm{C}_{2} \mathrm{H}_{4}$ production may result from an increase in ACC-malonyltransferase activity, thus from a decrease in ACC content as demonstrated in chickpea (Martinez-Reina et al., 1996), an inhibition of ACO activity (Corbineau et al., 1988; Gallardo et al., 1991), or a reduced expression of ACS and ACO (Argyris etal., 2008). In contrast, breaking of dormancy by various treatments (e.g., chilling, GAs, $\mathrm{NO}, \mathrm{HCN}$ ) leads to an increase in ethylene production 
(Kepczynski and Kepczynska, 1997; Arc et al., 2013). In Arabidopsis, the inductive effect of chilling is associated with a reduced expression of $A C O$, but in a transient induction of ACS (Narsai etal., 2011; Linkies and Leubner-Metzger, 2012). However, after-ripening of Sisymbrium officinale seeds inhibits expression of SoACS7 and SoACO2 which are involved in ethylene biosynthesis, during early seed incubation, but stimulates that of SoGA20ox2, SoGA3ox2, and SoGA2ox6 involved in GA metabolism (Iglesias-Fernandez and Matilla, 2009).

Data obtained using inhibitors of ethylene biosynthesis pathway or mutants altered in ethylene biosynthesis and signaling pathways demonstrated that endogenous ethylene plays a key role in the regulation of germination and dormancy. Incubation of seeds in the presence of aminoethoxyvinylglycine (AVG) and aminooxyacetic acid (AOA), inhibitors of ACS activity, $\mathrm{CoCl}_{2}$ and $\alpha$-aminoisobutyric acid $(\alpha$-AIB), inhibitors of ACO activity, or 2,5-norbornadiene (2,5 NBD) and silver thiosulfate (STS), inhibitors of ethylene action, allowed demonstration of the involvement of endogenous ethylene in germination and dormancy breakage (Kepczynski etal., 1977, 2003; Sinska and Gladon, 1989; Corbineau etal., 1990; Longan and Stewart, 1992; Gallardo et al., 1994; Hermann et al., 2007). In contrast, seed incubation in the presence of ACC, the direct precursor of ethylene, improves seed germination in numerous species such as lettuce (Fu and Yang, 1983), sunflower (Corbineau etal., 1990), cocklebur (Satoh etal., 1984), Amaranthus sp. (Kepczynski, 1986; Kepczynski et al., 1996b), chickpea (Gallardo et al., 1994), and sugar beet (Hermann et al., 2007). This effect of ACC suggests that ACO is potentially active, and that dormancy might result from insufficient ACC level due to low ACS activity.

It is important to notice that HCN, a co-product of ACC oxidation, can also break seed dormancy in apple (Perino et al., 1984; Lewak, 2011; Krasuska and Gniazdowska, 2012; Krasuska et al., 2014), sunflower (Oracz et al., 2008) and Amaranthus retroflexus (Kepczynski and Sznigir, 2014).

Using Arabidopsis lines altered in ethylene biosynthesis and signaling allowed to characterize the regulation of dormancy by ethylene (Table 2). Seeds of ethylene insensitive etr1 (ethylene resistant) as well as ein2 (ethylene insensitive 2) mutants display enhanced primary dormancy relative to wild type, probably due to high ABA sensitivity, whereas ctr1 (constitutive triple responses) mutant have a slightly enhanced rate of germination (Bleecker et al., 1988; Leubner-Metzger etal., 1998; Beaudoin et al., 2000; Ghassemian et al., 2000; Hall et al., 2001; Chiwocha et al., 2005; Subbiah and Reddy, 2010). EIN2 plays a key role in the ethylene signaling pathway, and loss of its function results in a hypersensitivy to salt and osmotic stress during germination and early seedling development in Arabidopsis (Wang et al., 2007). ERFs genes might also play a pivotal role in ethylene responsiveness and regulation of germination (Leubner-Metzger et al., 1998; Pirrello et al., 2006). FsERF1 expression is minimal in dormant beechnut embryo, but increases during moist chilling which breaks dormancy (Jimenez et al., 2005). In sunflower, ERF1 expression is fivefold higher in non-dormant than in dormant embryos, and expression is markedly stimulated by $\mathrm{HCN}$, which breaks dormancy (Oracz et al., 2008). In tomato (Solanum lycopersicon), SlERF2 transcript abundance is higher in germinating seeds than in non-germinating ones, and its overexpression

Table 2 | Dormancy and ABA sensitivity of various mutants of Arabidopsis thaliana affected in ethylene biosynthesis or signaling pathway.

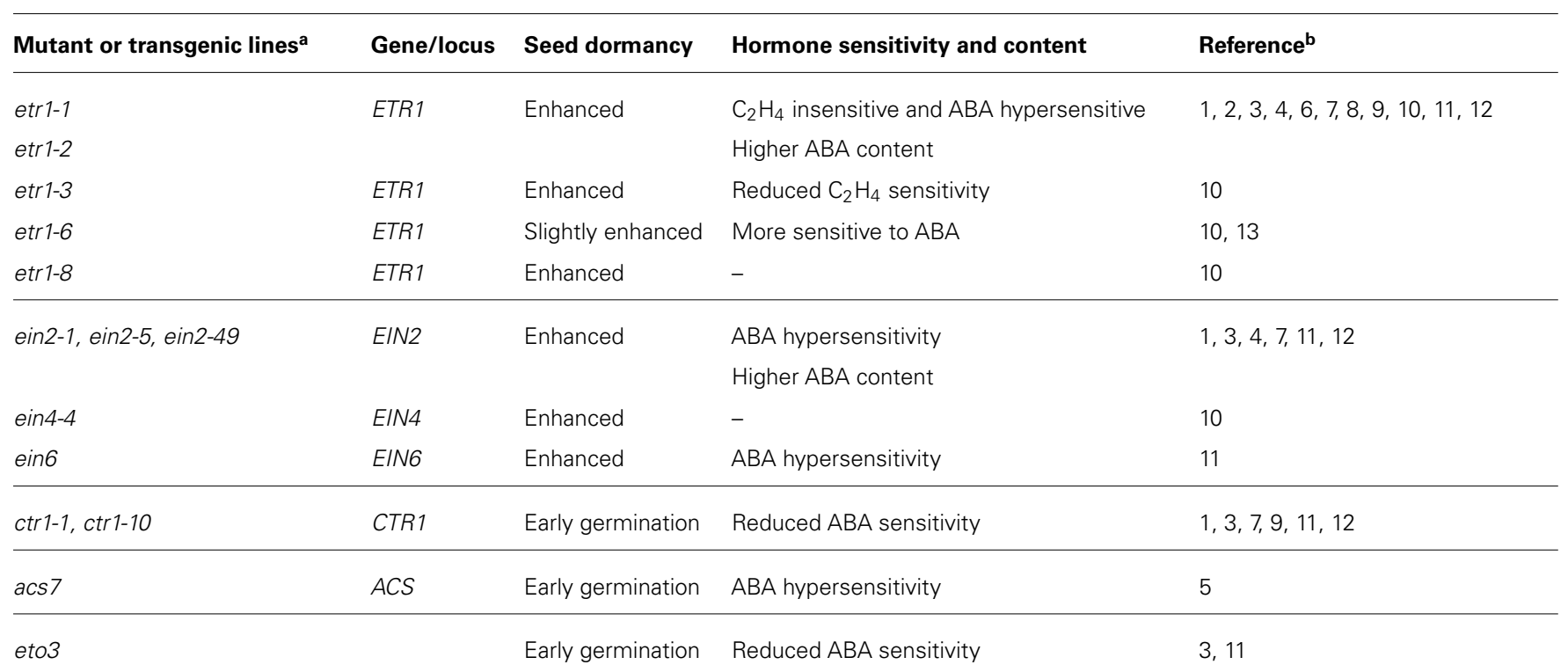

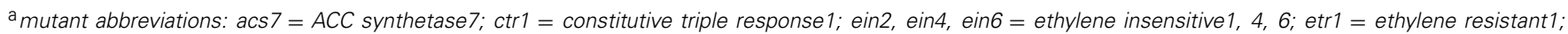
eto3 = ethylene overproducer3.

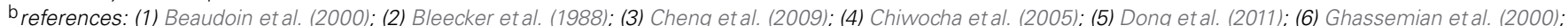

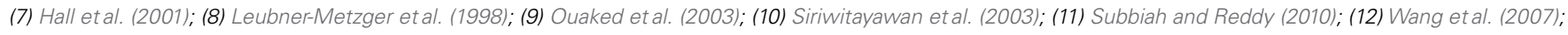
(13) Wilson etal. (2014a). 
in transgenic lines results in premature seed germination (Pirrello et al., 2006).

Transcriptional arrays have been used to draw a global view of gene expression in germinating and non-germinating seeds and core sets of genes were analyzed with respect to hormone responsive elements. The analysis of transcriptome data of dormant and after-ripened states in Arabidopsis performed by Cadman et al. (2006) showed that ACS2 gene expression was up-regulated in the dormant state and AtERF5 was up-regulated in germinating state. In lettuce, Argyris et al. (2008) have shown that ethylene responsive genes are regulated by thermo-inhibition; $A C O$ and ACS gene expression is reduced while CTR1, EIN2, ETR1 expression is increased at high temperature. These results point out the gap that exists between hormone metabolism and signaling regulation at the level of gene expression. In wheat seeds, 78 probesets annotated as ethylene metabolism and signaling genes have been differentially expressed between dormant and after-ripened seeds (Chitnis et al., 2014). ACO is represented by four probesets that are up-regulated in after-ripened wheat seeds but no ACS corresponding probeset has been found. Ethylene signaling element as reversion to ethylene sensitivity 1, ERS1, EBF1 (EIN3 binding box protein1), prohibitin 3 or ERF have been shown to be up-regulated in after-ripened seeds at 12 or $24 \mathrm{~h}$ of imbibition. The number of genes related to ethylene involved in germination is underestimated since only direct known ethylene signaling components are targeted for analysis in omic studies. It has been shown that treatment with ACC of 7 days germinated seedlings triggers change in expression of 544 genes, among them 244 were common to seeds given an ABA treatment (Nemhauser et al., 2006). These results have been used to compare genes regulated in Lepidium seed tissues during germination (Linkies et al., 2009). Pectate Lyase 1, Argos-like, Expansin A2, B-1,3-glucanase and chitinase B which play an important role in endosperm weakening and/or radicle growth in germination of Lepidium seeds, are proposed as putative ethylene response down-stream genes. Cell wall loosening enzymes expressed in endosperm are also controlled by both ABA and GA (Groot et al., 1988; Toorop et al., 2000).

\section{ETHYLENE CROSSTALK WITH ABA/GAs AND SEED GERMINATION INTERRELATIONSHIP BETWEEN ETHYLENE AND ABA}

The antagonistic effects of $\mathrm{ABA}$ and ethylene in the regulation of seed germination and dormancy have been extensively studied (Leubner-Metzger et al., 1998; Beaudoin et al., 2000; Kucera et al., 2005; Matilla and Matilla-Vazquez, 2008; Linkies et al., 2009; Arc et al., 2013). Ethylene overcomes the inhibitory action of ABA on germination of numerous species among which are Amaranthus caudatus (Kepczynski, 1986), Chenopodium album (Karssen, 1976), cotton (Halloin, 1976), tobacco (Nicotiana tabacum), and Arabidopsis (Leubner-Metzger et al., 1998). In Arabidopsis and Lepidium sativum, ethylene also counteracts the inhibition by ABA of endosperm cap weakening and rupture (Linkies et al., 2009). On the contrary, ABA increases the ethylene requirement in order to release dormancy in sunflower (Corbineau and Côme, 1995, 2003) and Amaranthus caudatus (Kepczynski et al., 2003). The negative interaction between ABA and ethylene is also supported by data obtained with various mutants affected in the signaling pathway of both hormones. Ethylene insensitive mutants (etr1, ein2, and ein6) are hypersensitive to ABA, whereas seeds of ein3, ein4, ein5, and ein7 germinate normally. Conversely, eto1, eto3, and ctr 1 mutants (characterized by an increase in $\mathrm{C}_{2} \mathrm{H}_{4}$ production) exhibit a reduced sensitivity to ABA (Table 2; Beaudoin et al., 2000; Ghassemian et al., 2000; Subbiah and Reddy, 2010). Loss of function of CRT1 enhances the tolerance to ABA of abil-1 seeds (Beaudoin et al., 2000). Genetic approaches, using double mutants obtained by crossing ethylene insensitive mutants (ctr1, ein1, ein3, and ein6) with aba2 mutant, demonstrate that $\mathrm{ABA}$ and $\mathrm{C}_{2} \mathrm{H}_{4}$ may also act in parallel, since they exibit phenotypes resulting from both ABA deficiency and altered ethylene sensitivity (Cheng et al., 2009).

Although ACC and exogenous ethylene do not affect ABA content in Lepidium sativum (Linkies et al., 2009) and sugar beet (Hermann et al., 2007), Arabidopsis seeds from ethylene insensitive mutants, etr1 and ein2, have a higher ABA content than that of wild type seeds (Kende et al., 1998; Beaudoin et al., 2000; Ghassemian et al., 2000; Chiwocha et al., 2005; Wang et al., 2007). For example, mutation in ETR1 results in an 8-fold higher ABA content in mature seeds than in wild type, probably due to a decrease in ABA conjugation (Chiwocha et al., 2005). Loss of function of ACS7, one of type 3 ACS with a very short C-terminus and no phosphorylation site, results in reduced $\mathrm{C}_{2} \mathrm{H}_{4}$ emission and hypersensitivity to ABA, consequently conferring abiotic stress tolerance to Arabidopsis seeds (Dong et al., 2011). ABA accumulation is also associated with stimulation of ABA biosynthesis through an upregulation of NCED and a down-regulation of CYP707A2 in seeds of the etr1 mutant (Cheng et al., 2009), or an up-regulation of NCED3 associated with an up-regulation of $A B A 1$ in ein2 seeds (Wang et al., 2007).

Inhibition of germination by $\mathrm{ABA}$ is associated with an inhibition of in vivo ACO activity and is correlated with a reduction in ACO transcript accumulation (Bailly et al., 1992; Petruzzelli etal., 2000, 2003; Linkies et al., 2009), leading to a reduction of ethylene production (Kepczynski and Kepczynska, 1997; Matilla, 2000). In Arabidopsis, accumulation of $A C O 1$ and $A C O 2$ transcripts during germination is inhibited by $\mathrm{ABA}$, and the high level of $A C O 1$ transcript in ABA-insensitive mutants suggest a tight regulation of ACO expression by ABA (Penfield et al., 2006; Carrera et al., 2008; Linkies et al., 2009). In Lepidium sativum, ABA inhibits expression of both ACO1 and ACO2 in the endosperm cap (Linkies et al., 2009). Upregulation of $A C O$ transcript has also been detected by microarray analysis in the aba2 mutant in Arabidopsis (Cheng etal., 2009). In contrast, there is an ABA-mediated up-regulation of ACC accumulation and ACO expression in sugar beet seeds (Hermann et al., 2007).

\section{INTERRELATIONSHIP BETWEEN ETHYLENE AND GAs}

Gibberellins improve the germination of dormant seeds in numerous species whose dormancy is broken by ethylene, ethephon, or ACC (c.f. Table 1). Both hormones promote the germination of primary dormant seeds of Arabidopsis (Ogawa et al., 2003; Siriwitayawan et al., 2003), Amaranthus retroflexus (Kepczynski et al., 1996b; Kepczynski and Sznigir, 2014), beechnut (Calvo 
et al., 2004a,b), apple (Kepczynski et al., 1977; Sinska and Gladon, 1984; Sinska, 1989; Lewak, 2011), and Sisymbrium officinale (Iglesias-Fernandez and Matilla, 2010). They also break secondary dormancy in Rumex crispus (Samimy and Khan, 1983) and cocklebur seeds (Esashi et al., 1975), and thermodormancy in lettuce achenes (Keys et al., 1975). In Arabidopsis, $\mathrm{C}_{2} \mathrm{H}_{4}$ restores the germination of the GA-deficient mutant ga1-3 (Karssen et al., 1989), and $\mathrm{GA}_{3}$ stimulates that of the etr1 mutant (Bleecker et al., 1988), while no stimulatory effect is noted on the germination of the GAdeficient gib-1 mutant in tomato (Groot and Karssen, 1987). All these data suggest that GAs and ethylene pathways interact (Brady and McCourt, 2003; Feurtado and Kermode, 2007; Matilla and Matilla-Vazquez, 2008; Miransari and Smith, 2014).

In beechnut, incubation of embryos in the presence of $\mathrm{GA}_{3}$ results in an accumulation of ACC and an increase in ACC oxidase activity and $\mathrm{C}_{2} \mathrm{H}_{4}$ production, concomitant with an increased expression of FsACO1 (Calvo et al., 2004a). Similarly, the improving effect of $\mathrm{GA}_{4}$ on the germination of Arabidopsis ga1-3 mutant seeds is associated with an increase in AtACO (Ogawa etal., 2003). Decrease of the expression of FsACO1 in the presence of paclobutrazol, a GAs biosynthesis inhibitor, confirms that GAs activates the ethylene biosynthesis pathway (Calvo et al., 2004a,b). However, in Sisymbrium officinale, IglesiasFernandez and Matilla (2010) demonstrate that expression of SoACS7 and SoACO2 during germination is inhibited by paclobutrazol, but is not affected by application of either ethrel or $\mathrm{GA}_{4+7}$. In addition, the up-regulation of AtERS1 (ETHYLENE RESPONSE SENSOR encoding a member of ethylene receptor family) in Arabidopsis in the presence of $\mathrm{GA}_{4}$ (Ogawa etal., 2003) and of an EIN-3 like in beechnut in the presence of $\mathrm{GA}_{3}$ (Lorenzo et al., 2000) suggest an effect of GAs on ethylene response.

Numerous data also suggest that ethylene stimulates seed germination by affecting the GAs biosynthesis or signaling pathway. $\mathrm{GA}_{1}, \mathrm{GA}_{4}$, and $\mathrm{GA}_{7}$ strongly accumulate in dry mature seeds of the etr1-2 Arabidopsis mutant relative to wild type, and both $\mathrm{GA}_{4}$ and $\mathrm{GA}_{7}$ contents remain higher than in wild type during the two first days of imbibition (Chiwocha et al., 2005). The changes in GA content during germination suggest that lack of ETR1, i.e., of ethylene signaling pathway, results (i) in alteration of GAs biosynthesis pathway, and (ii) in a requirement for higher levels of GAs than wild type, to promote germination (Chiwocha et al., 2005). In beechnut, expression of FsGA20ox1, which is involved in the synthesis of active GAs, remains low in stratified seeds (i.e., non-dormant seeds) and seeds treated with $\mathrm{GA}_{3}$ or ethephon, but inhibition of ethylene biosynthesis by AOA (2-aminoxyacetic acid) results in an increase in this transcript indicating the involvement of ethylene in the regulation of GA biosynthesis (Calvo et al., 2004b). Studies of expression of genes involved in GA synthesis (SoGA3ox2 and SoGA20ox2) and degradation (SoGA2ox6) during imbibition of Sisymbrium officinale seeds in the presence of $\mathrm{GA}_{4+7}$, ethylene, and inhibitors of GA synthesis or ethylene synthesis and signaling, indicate that GA biosynthesis is strongly regulated by GA and ethylene (Iglesias-Fernandez and Matilla, 2010).

Gibberellin signaling pathways depend on DELLA proteins including GAI (GA INSENSITIVE), RGA (REPRESSOR OF ga1-3), RGL1 (RGA LIKE1), RGL2 and RGL3 (Sun and Gubler, 2004; Davière and Achard, 2013). GAs destabilizes the DELLA proteins, which act as growth repressors by targeting GAs for ubiquitination and degradation (Dill et al., 2004). In Arabidopsis, Achard et al. $(2003,2007)$ reported that a part of ethylene action on hypocotyl growth and floral transition was mediated via its effects on the DELLA proteins. This may be true too in the control of germination since DELLA proteins seem to play a key role in the regulation of seed germination (Lee et al., 2002; Tyler et al., 2004; Cao et al., 2006; Steber, 2007; Piskurewicz et al., 2008; Schwechheimer, 2008). Thus, the seed GA content and responsiveness may result from a regulation of DELLA accumulation by ethylene.

\section{ROS AND ETHYLENE INTERACT TO REGULATE SEED GERMINATION}

It has been shown in various seed species (Oracz et al., 2007; Ishibashi et al., 2008, 2013; Müller et al., 2009; Bahin et al., 2011), including Arabidopsis (Liu et al., 2010; Leymarie et al., 2012), that radicle protrusion is associated with and/or required a controlled accumulation of ROS. Regarding the role of plant hormones in seed germination and dormancy, several studies have investigated the possible relationship between metabolic and signaling pathways of these hormones, mainly ABA and GAs, and ROS homeostasis (Bailly et al., 2008). Up-to-date, however, the relationship between ROS and ethylene has been scarcely studied within the context of seed germination, although this is well documented in other contexts such as plant pathogen interactions (Mersmann et al., 2010) or cell death regulation (Overmyer et al., 2003).

In sunflower embryos, whose dormancy is released by exogenous ethylene (Corbineau etal., 1990), it has been recently demonstrated that ethylene markedly enhanced ROS accumulation within dormant embryonic axes, probably through the activation of NADPH oxidase (El-Maarouf-Bouteau et al., 2014). Whether ethylene produced in response to ROS has a direct effect on cell wall properties and cell elongation or if it stimulates cell signaling pathways related to germination, is however not known. Contrasting results obtained by Lin et al. (2012, 2013) demonstrates that ethylene decreases ROS content in Arabidopsis seeds germinating under salinity stress. In the case of the former species, ethylene has an antagonistic effect to ROS that are detrimental for germination, probably because their production increases to excessive levels in response to stress. This highlights the plasticity of seed responses to ROS but also the complexity of their interaction with ethylene (Bailly et al., 2008).

Several authors have also studied the effect of ROS on ethylene production during seed germination. Dormant sunflower embryos treated by methylviologen, a ROS generating compound, germinate rapidly at temperatures that would otherwise prevent their germination (Oracz et al., 2007). However, this improving effect is not associated with an increase in ethylene production which peaks at the time radicle elongates, and which therefore must be considered as a post-germinative event (El-MaaroufBouteau et al., 2014). These authors propose that ethylene might participate in association with ROS to facilitate the initiation of cell elongation, the first visible symptom of germination. In dormant apple embryos, Gniazdowska et al. (2010) suggest 
that the improving effect of $\mathrm{NO}$ and $\mathrm{HCN}$ results from a transient ROS production leading to an ethylene production required in termination of the sensu stricto germination process before radicle elongation and propose that this might result from a nonenzymatic oxidation of ACC. Ishibashi et al. (2013) have proposed that ROS produced in soybean (Glycine max) embryonic axes during imbibition induces ethylene production, which promotes cell elongation in the radicle. However, in that case, ethylene was measured after the onset of radicle protrusion, and this production was probably more related to the kinetics of seedling elongation than on a direct effect of $\mathrm{H}_{2} \mathrm{O}_{2}$. In contrast, in pea, which germination is not strongly regulated by ethylene, Barba-Espin et al. (2011) demonstrate that $\mathrm{H}_{2} \mathrm{O}_{2}$ treatment results in a reduction in PsACS2 transcript abundance consistent with a decrease in ACC content. These results suggest that ROS and ethylene probably do not interact directly, but rather through a complex hormonal network (Diaz-Vivancos et al., 2013).

All together these data suggest that the interaction between ROS and ethylene in seeds can operate in both directions, depending on the physiological context of germination, i.e., on the environmental conditions prevailing during imbibition, and is highly species related. One can predict that the use of seeds of the plant model Arabidopsis will help decipher the molecular bases of this interaction. In particular it will be interesting to determine whether ROS can trigger expression of the ethylene signaling pathway components and vice versa. For example, Oracz et al. (2009) has demonstrated the occurrence of such a cross talk, since the treatment of dormant sunflower embryos by methylviologen induced the expression of ETR2 and of the transcription factor ERF1. The involvement of ethylene transcription factors in response to ROS appears to be worth investigating since studies with other plant systems have also implicated such a relationship (Sewelam et al., 2013).

\section{CONCLUSION: NETWORK BETWEEN ETHYLENE, PLANT HORMONES, AND ROS}

Seed germination is regulated by ethylene in a complex signaling network, which is also operational in numerous developmental processes, including vegetative growth, flowering timing, fruit ripening and organ senescence and abscission (Yoo et al., 2009; Muday et al., 2012; Arc et al., 2013). As mentioned above, ethylene interacts with $\mathrm{ABA}$ and GAs, both hormones being essential regulators of germination and dormancy (Feurtado and Kermode, 2007; Nambara et al., 2010; Nonogaki et al., 2010; Miransari and Smith, 2014). Thus, the improving effect of ethylene may occur via the involvement of $\mathrm{C}_{2} \mathrm{H}_{4}$-GAs-ABA crosstalk but whether its action is direct or indirect needs clarification. Research on the effect of $\mathrm{ABA}$ and GAs on $\mathrm{C}_{2} \mathrm{H}_{4}$ biosynthesis and signaling pathways, especially in seeds, would then require further investigation, specifically in relation with ROS. Figure 2 summarizes the current data concerning ABA-GAs- $\mathrm{C}_{2} \mathrm{H}_{4}$ networks based on genetic analyses, microarray data, and physiological studies. ABA inhibits the $\mathrm{C}_{2} \mathrm{H}_{4}$ biosynthesis pathway via an inhibitory action on ACO activity and on the ACO transcript accumulation. On the contrary, $\mathrm{C}_{2} \mathrm{H}_{4}$ counteracts both ABA synthesis and signaling, ETR1 having a key role. In addition, $\mathrm{C}_{2} \mathrm{H}_{4}$ affects the synthesis of GAs via modification of

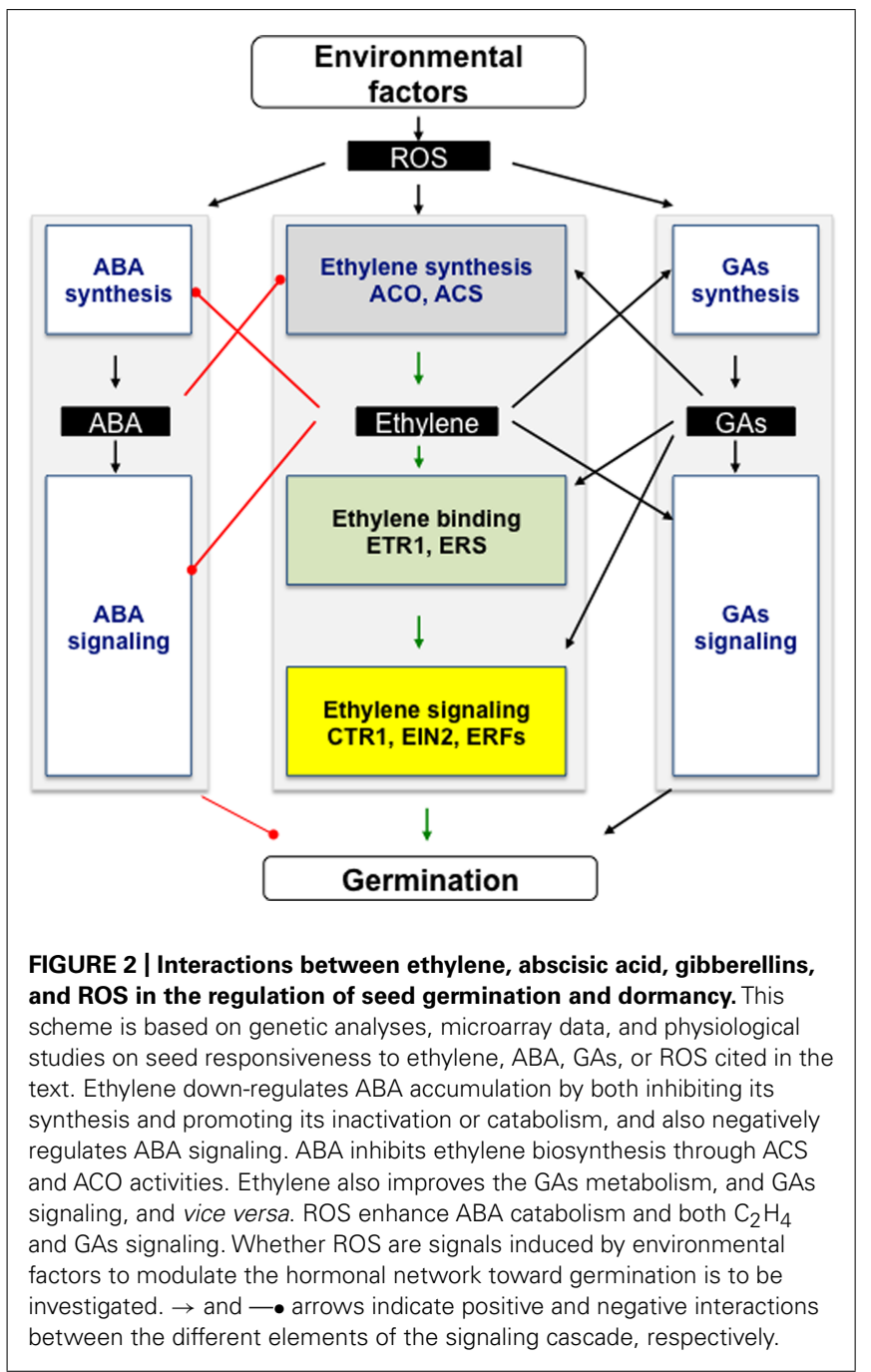

expression of genes (GA3ox and GA20ox) involved in GAs synthesis. Ethylene also probably modifies the GAs signaling pathway via a regulation of DELLA proteins, as demonstrated in growth processes (Achard et al., 2003, 2007). To add to the complexity of the ABA-GAs- $\mathrm{C}_{2} \mathrm{H}_{4}$ network, there are antagonistic interactions between $\mathrm{ABA}$ and $\mathrm{GAs}, \mathrm{C}_{2} \mathrm{H}_{4}$ and brassinosteroids, jasmonates and auxins (Wang et al., 2002; Brady and McCourt, 2003; Weiss and Ori, 2007; Finkelstein et al., 2008; Matilla and Matilla-Vazquez, 2008; Cheng et al., 2009; Divi et al., 2010; Linkies and LeubnerMetzger, 2012). ROS also regulate seed germination through hormonal networks, in particular with ABA and GAs (Bethke et al., 2007; Liu et al., 2010; Diaz-Vivancos et al., 2013). It would be then important to discriminate the hierarchy of the different signaling pathways, and their role as sensor of environmental signals.

Omics studies are now available in the field of seed germination but efforts to develop transcriptomic analysis of ethylene action are required to understand ethylene involvement in seed germination. Analysis of the effects of ethylene on specific cellular processes highlighted by dormancy and germination studies such as transcription regulation, cell cycle activity and endosperm weakening 
should help to understand the regulatory network of germination process in seeds. Moreover, although hormonal signaling network share common components, they may work in specific territories in seeds.

\section{REFERENCES}

Abeles, F. B. (1986). Role of ethylene in Lactuca sativa cv Grand Rapids seed germination. Plant Physiol. 81, 780-787. doi: 10.1104/pp.81.3.780

Achard, P., Baghour, M., Chapple, A., Hedden, P., Van Der Straeten, D., Genschik, P., et al. (2007). The plant stress hormone ethylene controls floral transition via DELLA-dependent regulation of floral meristem-identity genes. Proc. Natl. Acad. Sci. U.S.A. 104, 6484-6489. doi: 10.1073/pnas.061 0717104

Achard, P., Vriezen, W. H., Van Der Straeten, D., and Harberd, N. P. (2003). Ethylene regulates Arabidopsis development via the modulation of DELLA protein growth repressor function. Plant Cell 15, 2816-2825. doi: 10.1105/tpc.015685

Arc, E., Sechet, J., Corbineau, F., Rajjou, L., and Marion-Poll, A. (2013). ABA crosstalk with ethylene and nitric oxide in seed dormancy and germination. Front. Plant Sci. 4:63. doi: 10.3389/fpls.2013.00063

Argyris, J., Dahal, P., Hayashi, E., Still, D. W., and Bradford, K. J. (2008). Genetic variation for lettuce seed thermoinhibition is associated with temperature-sensitive expression of abscisic acid, gibberellin, and ethylene biosynthesis, metabolism, and response genes. Plant Physiol. 148, 926-947. doi: 10.1104/pp.108. 125807

Bahin, E., Bailly, C., Sotta, B., Kranner, I., Corbineau, F., and Leymarie, J. (2011). Crosstalk between reactive oxygen species and hormonal signaling pathways regulates grain dormancy in barley. Plant Cell Environ. 34, 980-993. doi: 10.1111/j.1365-3040.2011.02298.x

Bailly, C., Corbineau, F., and Côme, D. (1992). The effects of abscisic acid and methyl jasmonate on 1-aminocyclopropane 1-carboxylic acid conversion to ethylene in hypocotyl segments of sunflower seedlings, and their control by calcium and calmodulin. Plant Growth Regul. 11, 349-355. doi: 10.1007/BF00130641

Bailly, C., El-Maarouf-Bouteau, H., and Corbineau, F. (2008). From intracellular signaling networks to cell death: the dual role of reactive oxygen species in seed physiology. C. R. Biol. 331, 806-814. doi: 10.1016/j.crvi.2008.07.022

Barba-Espin, G., Diaz-Vivancos, P., Job, D., Belghazi, M., Job, C., and Hernandez, J. A. (2011). Understanding the role of $\mathrm{H}_{2} \mathrm{O}_{2}$ during pea seed germination: a combined proteomic and hormone profiling approach. Plant Cell Environ. 34, 1907-1919. doi: 10.1111/j.1365-3040.2011.02386.x

Beaudoin, N., Serizet, C., Gosti, F., and Giraudat, J. (2000). Interactions between abscisic acid and ethylene signaling cascades. Plant Cell 12, 1103-1115. doi: 10.1105/tpc.12.7.1103

Bebawi, F. F., and Eplee, R. E. (1986). Efficacy of ethylene as a germination stimulant of Striga hermonthica. Weed Sci. 34, 694-698.

Bethke, P. C., Libourel, I. G. L., and Jones, R. L. (2007). "Nitric oxide in seed dormancy and germination," in Annual Plant Reviews, Vol. 27, Seed Development, Dormancy and Germination, eds K. Bradford and H. Nonogaki (Oxford: Blackwell Publishing Ltd), 153-175.

Bewley, J. D. (1997). Seed germination and dormancy. Plant Cell 9, 1055-1066. doi: 10.1105/tpc.9.7.1055

Bewley, J. D., and Black, M. (1994). Seeds: Physiology of Development and Germination. NewYork: Plenum Press. doi: 10.1007/978-1-4899-1002-8

Bleecker, A. B., Estelle, M. A., Somerville, C., and Kende, H. (1988). Insensitivity to ethylene conferred by a dominant mutation in Arabidopsis thaliana. Science 241, 1086-1089. doi: 10.1126/science. 241.4869 .1086

Bleecker, A. B., and Kende, H. (2000). Ethylene: a gaseous signal molecule in plants. Annu. Rev. Cell Dev. Biol. 16, 1-18. doi: 10.1146/annurev.cellbio.16.1.1

Brady, S. M., and McCourt, P. (2003). Hormone cross-talk in seed dormancy. J. Plant Growth 22, 25-31. doi: 10.1007/s00344-003-0018-7

Brown, N. A. C., and van Staden, J. (1997). Smoke as a germination cue: a review. Plant Growth Regul. 22, 115-124. doi: 10.1023/A:1005852018644

Burdett, A. N., and Vidaver, W. (1971). Synergistic action of ethylene with gibberellin or red light in germinating lettuce seeds. Plant Physiol. 48, 656-657. doi: 10.1104/pp.48.5.656

Cadman, C. S. C., Toorop, P. E., Hilhorst, H. W. M., and Finch-Savage, W. E. (2006). Gene expression profiles of Arabidopsis Cvi seeds during dormancy cycling indicate a common underlying dormancy control mechanism. Plant J. 46, 805822. doi: 10.1111/j.1365-313X.2006.02738.x
Calvo, A. P., Nicolas, C., Lorenzo, O., Nicolas, G., and Rodriguez, D. (2004a). Evidence for positive regulation by gibberellins and ethylene of ACC oxidase expression and activity during transition from dormancy to germination in Fagus sylvatica L. seeds. J. Plant Growth Regul. 23, 44-53. doi: 10.1007/s00344-0040074-7

Calvo, A. P., Nicolas, C., Nicolas, G., and Rodriguez, D. (2004b). Evidence of a crosstalk regulation of a GA 20-oxidase (FsGA20oxl) by gibberellins and ethylene during the breaking of dormancy in Fagus sylvatica seeds. Physiol. Plant. 120, 623-630. doi: 10.1111/j.0031-9317.2004.0270.x

Cao, D., Cheng, H., Wu, W., Soo, H. M., and Peng, J. (2006). Gibberellin mobilizes distinct DELLA-dependent transcriptomes to regulate seed germination and floral development in Arabidopsis. Plant Physiol. 142, 509-525. doi: 10.1104/pp.106.082289

Carrera, E., Holman, T., Medhurst, A., Dietrich, D., Footitt, S., Theodoulou, F. L., etal. (2008). Seed after-ripening is a discrete developmental pathway associated with specific gene networks in Arabidopsis. Plant J. 142, 1493-1510.

Cheng, W. H., Chiang, M. H., Hwang, S. G., and Lin, P. C. (2009). Antagonism between abscisic acid and ethylene in Arabidopsis acts in parallel with the reciprocal regulation of their metabolism and signaling pathways. Plant Mol. Biol. 71, 61-80. doi: 10.1007/s11103-009-9509-7

Chitnis, V. R., Gao, F., Yao, Z., Jordan, M. C., Park, S., and Ayele, B. T. (2014). After-ripening induced transcriptional changes of hormonal genes in wheat seeds: the cases of brassinosteroids, ethylene, cytokinin and salicylic acid. PLoS ONE 9:e87543. doi: 10.1371/journal.pone.0087543

Chiwocha, S. D. S., Cutler, A. J., Abrams, S. R., Ambrose, S. J., Yang, J., and Kermode, A. R. (2005). The ert1-2 mutation in Arabidopsis thaliana affects the abscisic acid, auxin, cytokinin and gibberellin metabolic pathways during maintenance of seed dormancy, moist-chilling and germination. Plant J. 42, 35-48. doi: 10.1111/j.1365-313X.2005.02359.x

Chonowski, M., Corbineau, F., and Côme, D. (1997). Physiological and biochemical changes induced in sunflower seeds by osmopriming and subsequent drying, storage and aging. Seed Sci. Res. 7, 323-332. doi: 10.1017/S0960258500 $00372 \mathrm{X}$

Corbineau, F. (2012). Markers of seed quality: from present to future. Seed Sci. Res. 22, S61-S68. doi: 10.1017/S0960258511000419

Corbineau, F., Bagniol, S., and Côme, D. (1990). Sunflower (Helianthus annuus L.) seed dormancy and its regulation by ethylene. Isr. J. Bot. 39, 313-325.

Corbineau, F., and Côme, D. (1992). "Germination of sunflower seeds and its regulation by ethylene," in Advances in the Science and Technology of Seeds, eds F. Jiarui and A. A. Khan (Beijing, NY: Science Press), 277-287.

Corbineau, F., and Côme, D. (1995). "Control of seed germination and dormancy by gaseous environment," in Seed Development and Germination, eds J. Kigel and G. Galili (New York: Marcel Dekker), 397-424.

Corbineau, F., and Côme, D. (2003). "Germination of sunflower seeds as related to ethylene synthesis and sensitivity - an overview," in Biology and Biotechnology of the Plant Hormone Ethylene III, eds M. Vendrell, H. Klee, J. C. Pech, and F. Romojaro (Amsterdam: IOS Press), 216-221.

Corbineau, F., Rudnicki, R. M., and Côme, D. (1988). Induction of secondary dormancy in sunflower seeds by high temperature. Possible involvement of ethylene biosynthesis. Physiol. Plant. 73, 368-373. doi: 10.1111/j.13993054.1988.tb00612.x

Cristescu, S. M., Persijn, S. T., Lintel Hekkert, S., and Harren, F. J. M. (2008). Laserbased systems for trace gas detection in life sciences. Appl. Phys. B 92, 343-349. doi: 10.1007/s00340-008-3127-y

Cutler, S. R., Rodriguez, P. L., Finkelstein, R. R., and Abrams, S. R. (2010). Abscisic acid: emergence of a core signaling network. Annu. Rev. Plant Biol. 61, 651-679. doi: 10.1146/annurev-arplant-042809-112122

Davière, J.-M., and Achard, P. (2013). Gibberellin signalling in plants. Development 140, 1147-1151. doi: 10.1242/dev.087650

Diaz-Vivancos, P., Barba-Espin, G., and Hernandez, J. A. (2013). Elucidating hormonal/ROS networks during germination: insights and perspectives. Plant Cell Rep. 32, 1491-1502. doi: 10.1007/s00299-013-1473-7

Dill, A., Thomas, S. G., Steber, C. M., and Sun, T.-p. (2004). The Arabidopsis F-box protein SLEEPY1 targets gibberellin signaling repressors for gibberellin-induced degradation. Plant Cell 16, 1392-1405. doi: 10.1105/tpc.020958

Divi, U. K., Rahman, T., and Krishna, P. (2010). Brassinosteroid-mediated stress tolerance in Arabidopsis shows interactions with abscisic acid, ethylene and salicylic acid pathways. BMC Plant Biol. 10:151. doi: 10.1186/1471-2229-10-151 
Dong, H., Zhen, Z., Peng, J., Chang, L., Gong, Q., and Wang, N. N. (2011). Loss of ACS7 confers abiotic stress tolerance by modulating ABA sensitivity and accumulation in Arabidopsis. J. Exp. Bot. 62, 4875-4887. doi: 10.1093/jxb/ err 143

Egley, G. H., and Dale, J. E. (1970). Ethylene, 2-chloroethylphosphonic acid and witchweed germination. Weed Sci. 18, 586-589.

El-Maarouf-Bouteau, H., Sajjad, Y., Bazin, J., Langlade, N., Cristescu, S. M., Balzergue, S., et al. (2014). Reactive oxygen species, abscisic acid and ethylene interact to regulate sunflower seed germination. Plant Cell Environ. doi: 10.1111/pce.12371 [Epub ahead of print].

Esashi, Y. (1991). "Ethylene and seed germination," in The Plant Hormone Ethylene, eds A. K. Mattoo and J. C. Suttle (Boca Raton, FL: CRC Press), 133-157.

Esashi, Y., Abe, Y., Ashino, H., Ishizawa, K., and Saitoh, K. (1989). Germination of cocklebur seeds and growth of their axial and cotyledonary tissues in response to $\mathrm{C}_{2} \mathrm{H}_{4}, \mathrm{CO}_{2}$ and/or $\mathrm{O}_{2}$ under water stress. Plant Cell Environ. 12, 183-190. doi 10.1111/j.1365-3040.1989.tb01931.x

Esashi, Y., Hata, Y., and Katoh, H. (1975). Germination of cocklebur seeds: interactions between gibberellic acid, benzyladenine, thiourea, KNO3 and gaseous factors. Aust. J. Plant Physiol. 2, 569-579. doi: 10.1071/PP9750569

Esashi, Y., and Leopold, A. C. (1969). Dormancy regulation in subterranean clover seeds by ethylene. Plant Physiol. 44, 1470-1472. doi: 10.1104/pp.44.10.1470

Esashi, Y., Okazaki, M., Yanai, N., and Hishinuma, K. (1978). Control of the germination of secondary dormant cocklebur seeds by various germination stimulants. Plant Cell Physiol. 19, 1497-1506.

Esashi, Y., Ooshima, Y., Abe, M., Kurota, A., and Satoh, S. (1986). CO 2 -enhanced $\mathrm{C}_{2} \mathrm{H}_{4}$ production in tissues of imbibed cocklebur seeds. Aust. J. Plant Physiol. 13, 417-429. doi: 10.1071/PP9860417

Feurtado, J. A., and Kermode, A. R. (2007). "A merging of paths: abscisic acid and hormonal cross-talk in the control of seed dormancy maintenance and alleviation,” in Annual Plant Reviews, Vol. 27, Seed Development, Dormancy and Germination, eds K. Bradford and H. Nonogaki (Oxford: Blackwell Publishing Ltd), 176-223. doi: 10.1002/9780470988848.ch8

Finkelstein, R. R., Reeves, W., Ariizumi, T., and Steber, C. (2008). Molecular aspects of seed dormancy. Annu. Rev. Plant Biol. 59, 387-415. doi: 10.1146/annurev.arplant.59.032607.092740

Fu, J. R., and Yang, S. F. (1983). Release of heat pretreatment-induced dormancy in lettuce seeds by ethylene or cytokinin in relation to the production of ethylene and the synthesis of 1-aminocyclopropane-1-carboxylic acid during germination. J. Plant Growth Regul. 2, 185-192. doi: 10.1007/BF02042247

Gallardo, M., Del Mar Delgado, M., Sanchez-Calle, I. M., and Matilla, A. J. (1991). Ethylene production and 1-aminocyclopropane-1-carboxylic acid conjugation in thermoinhibited Cicer arietinum L. seeds. Plant Physiol. 97, 122-127. doi: 10.1104/pp.97.1.122

Gallardo, M., Gallardi, M. E., Matilla, A., Munoz de Ruedo, P., and Sanchez-Calle, I. M. (1994). Inhibition of polyamine synthesis by cyclohexylamine stimulates the ethylene pathway and accelerates the germination of Cicer arietinum seeds. Physiol. Plant. 91, 9-16. doi: 10.1111/j.1399-3054.1994.tb00652.x

Ghassemian, M., Nambara, E., Cutler, S., Kawaide, H., Kamiya, Y., and McCourt, P. (2000). Regulation of abscisic acid signaling by the ethylene response pathway in Arabidopsis. Plant Cell 12, 1117-1126. doi: 10.1105/tpc.12.7.1117

Gniazdowska, A., Krasuska, U., and Bogatek, R. (2010). Dormancy removal in apple embryos by nitric oxide or cyanide involves modifications in ethylene biosynthetic pathway. Planta 232, 1397-1407. doi: 10.1007/s00425-010-1262-2

Gomez-Jimenez, M. C., Matilla, A. J., and Garrido, D. (1998). Isolation and characterization of a cDNA encoding an ACC oxidase from Cicer arietinum and its expression during embryogenesis and seed germination. Aust. J. Plant Physiol. 25, 765-773. doi: 10.1071/PP97166

Gorecki, R. J., Ashino, H., Satoh, S., and Esashi, Y. (1991). Ethylene production in pea and cocklebur seeds of differing vigour. J. Exp. Bot. 42, 407-414. doi: 10.1093/jxb/42.3.407

Graeber, K., Nakabayashi, K., Miatton, E., Leubner-Metzger, G., and Soppe, W. J. (2012). Molecular mechanisms of seed dormancy. Plant Cell Environ. 35, 17691786. doi: 10.1111/j.1365-3040.2012.02542.x

Groot, S. P., and Karssen, C. M. (1987). Gibberellins regulate seed germination in tomato by endosperm weakening: a study with gibberellin-deficient mutants. Planta 171, 525-531. doi: 10.1007/BF00392302

Groot, S. P., Kieliszewska-Rokicka, B., Vermeer, E., and Karssen, C. M. (1988). Gibberellin-induced hydrolysis of endosperm cell walls in gibberellin- deficient tomato seeds prior to radicle protrusion. Planta 174, 500-504. doi: 10.1007/BF00634479

Hall, B., Shakeel, S., and Schaller, G. (2007). Ethylene receptors: ethylene perception and signal transduction. J. Plant Growth Regul. 26, 118-130. doi: 10.1007/s00344007-9000-0

Hall, M. A., Moshkov, I. E., Novikova, G. V., Mur, L. A. J., and Smith, A. R. (2001). Ethylene signal perception and transduction: multiple paradigms? Biol. Rev. 76, 103-128. doi: 10.1017/S1464793100005649

Halloin, J. M. (1976). Inhibition of cotton seed germination with abscisic acid and its reversal. Plant Physiol. 57, 454-455. doi: 10.1104/pp.57.3.454

Hermann, K., Meinhard, J., Dobrev, P., Linkies, A., Pesek, B., Hess, B., et al. (2007). 1-amynocyclopropane-1-carboxylic acid and abscisic acid during the germination of sugar beet (Beta vulgaris L.): a comparative study of fruits and seeds. J. Exp. Bot. 58, 3047-3060. doi: 10.1093/jxb/erm 162

Hilhorst, H. W. M. (2007). "Definitions and hypotheses of seed dormancy," in Annual Plant Reviews, Vol. 27, Seed Development, Dormancy and Germination, eds K. Bradford and H. Nonogaki (Oxford: Blackwell Publishing Ltd), 50-71. doi: 10.1002/9780470988848.ch3

Hilhorst, H. W. M., Finch-Savage, W. E., Buitink, J., Bolingue, W., and LeubnerMetzger, G. (2010). "Dormancy in plant seeds," in Dormancy and Resistance in Harsh Environment, eds E. Lubzens, J. Cerdà, and M. Clarck (Berlin: Springer), 43-67. doi: 10.1007/978-3-642-12422-8_4

Iglesias-Fernandez, R., and Matilla, A. (2009). After-ripening alters the gene expression pattern of oxidases involved in the ethylene and gibberellin pathways during early imbibition of Sisymbrium officinale L. seeds. J. Exp. Bot. 60, 1645-1661. doi: 10.1093/jxb/erp029

Iglesias-Fernandez, R., and Matilla, A. (2010). Genes involved in ethylene and gibberellins metabolism are required for endosperm-limited germination of Sisymbrium officinale L. seeds. Planta 231, 653-664. doi: 10.1007/s00425-0091073-5

Ishibashi, Y., Koda, Y., Zheng, S.-H., Yuasa, T., and Iwaya-Inoue, M. (2013). Regulation of soybean seed germination through ethylene production in response to reactive oxygen species. Ann. Bot. 111, 95-102. doi: 10.1093/aob/ $\operatorname{mcs} 240$

Ishibashi, Y., Yamamoto, K., Tawaratsumida, T., Yuasa, T., and Iwaya-Inoue, M. (2008). Hydrogen peroxide scavenging regulates germination ability during wheat (Triticum aestivum L.) seed maturation. Plant Signal. Behav. 3, 183-188. doi: $10.4161 /$ psb.3.3.5540

Jimenez, J. A., Rodriguez, D., Calvo, A. P., Mortensen, L. C., Nicolas, G., and Nicolas, C. (2005). Expression of a transcription factor (FsERF1) involved in ethylene signaling during the breaking of dormancy in Fagus sylvatica seeds. Physiol. Plant. 125, 373-380. doi: 10.1111/j.1399-3054.2005.00571.x

Jones, J. F., and Hall, M. A. (1984). Studies on the requirement for carbon dioxide and ethylene for germination of Spergula arvensis L. seeds. Plant Sci. Lett. 16, 87-93. doi: 10.1016/0304-4211(79)90012-9

Ju, C., Yoon, G. M., Shemansky, J. M., Lin, D. Y., Ying, Z. I., Chang, J., et al. (2012). CTR1 phosphorylates the central regulator EIN2 to control ethylene hormone signaling from the ER membrane to the nucleus in Arabidopsis. Proc. Natl. Acad. Sci. U.S.A. 109, 19486-19491. doi: 10.1073/pnas.1214848109

Karssen, C. M. (1976). Two sites of hormonal action during germination of Chenopodium album seeds. Physiol. Plant. 36, 264-270. doi: 10.1111/j.13993054.1976.tb04426.x

Karssen, C. M., Zagórsky, S., Kepczynski, J., and Groot, S. P. C. (1989). Key role for endogenous gibberellins in the control of seed germination. Ann. Bot. 63, 71-80.

Katoh, H., and Esashi, Y. (1975). Dormancy and impotency of cocklebur seeds. I. $\mathrm{CO}_{2}, \mathrm{C}_{2} \mathrm{H}_{4}, \mathrm{O}_{2}$ and high temperature. Plant Cell Physiol. 16, 687-696. doi: $10.1093 / \mathrm{jxb} / 35.10 .1515$

Kende, H. (1993). Ethylene biosynthesis. Annu. Rev. Plant Physiol. Plant Mol. Biol. 44, 283-307. doi: 10.1146/annurev.pp.44.060193.001435

Kende, H., van der Knaap, E., and Cho, H. T. (1998). Deepwater rice: a model plant to study stem elongation. Plant Physiol. 118, 1105-1110. doi: 10.1104/pp.118.4.1105 Kendrick, M. D., and Chang, C. (2008). Ethylene signaling: new levels of complexity and regulation. Curr. Opin. Plant Biol. 11, 479-485. doi: 10.1016/j.pbi.2008.06.011

Kepczynski, J. (1986). Inhibition of Amaranthus caudatus seed germination by polyethylene glycol-6000 and abscisic acid and its reversal by ethephon or aminocyclopropane-1-carboxylic acid. Physiol. Plant. 67, 588-591. doi: 10.1111/j.1399-3054.1986.tb05060.x 
Kepczynski, J., Bihun, M., and Kepczynska, E. (1996a). Induction and release of secondary dormancy in Amaranthus caudatus L. seeds. Plant Physiol. Biochem. Special Issue S03-S50, 42.

Kepczynski, J., Corbineau, F., and Côme, D. (1996b). Responsiveness of Amaranthus retroflexus seeds to ethephon, 1-aminocyclopropane-1-carboxylic acid and gibberellic acid in relation to temperature and dormancy. Plant Growth Regul. 20, 259-265. doi: 10.1007/BF00043316

Kepczynski, J., Bihun, M., and Kepczynska, E. (2003). The release of secondary dormancy by ethylene in Amaranthus caudatus L. seeds. Seed Sci. Res. 13, 69-74. doi: 10.1079/SSR2002125

Kepczynski, J., and Karssen, C. M. (1985). Requirement for the action of endogenous ethylene during germination of non-dormant seeds of Amaranthus caudatus. Physiol. Plant. 63, 49-52. doi: 10.1111/j.1399-3054.1985.tb02816.x

Kepczynski, J., and Kepczynska, E. (1993). "The effect of putrescine, ethephon and ACC on germination of thermodormant Amaranthus paniculatus L. seed," in Basic and Applied Aspects of Seed Biology, Fourth International Workshop on Seeds, ed D. Côme and F. Corbineau (Paris: ASFIS), 537-554.

Kepczynski, J., and Kepczynska, E. (1997). Ethylene in seed dormancy and germination. Physiol. Plant. 101, 720-726. doi: 10.1034/j.1399-3054.1997.1010407.x

Kepczynski, J., Rudnicki, R. M., and Khan, A. A. (1977). Ethylene requirement for germination of partly after-ripened apple embryo. Physiol. Plant. 40, 292-295. doi: 10.1111/j.1399-3054.1977.tb04075.x

Kepczynski, J., and Sznigir, P. (2014). Participation of GA3, ethylene, NO and HCN in germination of Amaranthus retroflexus L. seeds with various dormancy levels. Acta Physiol. Plant. 36, 1463-1472. doi: 10.1007/s11738-014-1524-x

Ketring, D. L., and Morgan, P. W. (1969). Ethylene as a component of the emanations from germinating peanut seeds and its effect on dormant Virginia-type seeds. Plant Physiol. 44, 326-330. doi: 10.1104/pp.44.3.326

Ketring, D. L., and Morgan, P. W. (1972). Physiology of oil seeds. IV. Role of endogenous ethylene and inhibitory regulators during natural and induced afterripening of dormant Virginia-type peanut seeds. Plant Physiol. 50, 382-387. doi: $10.1104 /$ pp.50.3.382

Ketring, D. L., Morgan, P. W., and Powell, R. D. (1974). "Relations of ethylene production to germinability and growth of two oil seeds, cotton and peanuts," in Plant growth substances 1973, ed. Y. Sumiki (Tokyo: Hirokawa), 891-899.

Keys, R. D., Smith, O. E., Kumamoto, J., and Lyon, J. J. (1975). Effect of gibberellic acid, kinetin, and ethylene plus carbon dioxide on the thermodormancy of lettuce seed (Lactuca sativa L. cv Mesa 659). Plant Physiol. 56, 826-829. doi: 10.1104/pp.56.6.826

Khan, A. A. (1994). ACC-derived ethylene production, a sensitive test for seed vigor. J. Am. Soc. Hort. Sci. 119, 1083-1090.

Khan, M. A., Ansari, R., Gul, B., and Li, W. Q. (2009). Dormancy and germination responses of halophyte seeds to the application of ethylene. C. R. Biol. 332, 806815. doi: 10.1016/j.crvi.2009.05.002

Kucera, B., Cohn, M. A., and Leubner-Metzger, G. (2005). Plant hormone interactions during seed dormancy release and germination. Seed Sci. Res. 15, 281-307. doi: $10.1079 /$ SSR2005218

Krasuska, U., Ciacka, K., Debska, K., Bogatek, R., and Gniazdowska, A. (2014) Dormancy alleviation by NO or HCN leading to decline of protein carbonylation levels in apple (Malus domestica Borkh.) embryos. J. Plant Physiol. 171, 11321141. doi: 10.1016/j.jplph.2014.04.015

Krasuska, U., and Gniazdowska, A. (2012). Nitric oxide and hydrogen cyanide as regulating factors of enzymatic antioxidant system in germinating apple embryos. Acta Physiol. Plant. 34, 683-692. doi: 10.1007/s11738-011-0868-8

Lee, S., Cheng, H., King, K. E., King, K. E., Wang, W., He, Y., et al. (2002). Gibberellin regulates Arabidopsis seed germination via RGL2, a GAI/RGA-like gene whose expression is up-regulated following imbibition. Genes Dev. 16, 646-658. doi: 10.1101/gad.969002

Leubner-Metzger, G., Petruzzelli, L., Waldvogel, R., Vogeli-Lange, R., and Meins, F. (1998). Ethylene-responsive element binding protein (EREBP) expression and the transcriptional regulation of class I beta-1,3-glucanase during tobacco seed germination. Plant Mol. Biol. 38, 785-795. doi: 10.1023/A:1006040425383

Lewak, S. (2011). Metabolic control of embryonic dormancy in apple seed: seven decades of research. Acta Physiol. Plant. 33, 1-24. doi: 10.1007/s11738-0100524-8

Leymarie, J., Vitkauskaite, G., Hoang, H. H., Gendreau, E., Chazoule, V., Meimoun, P., et al. (2012). Role of reactive oxygen species in the regulation of Arabidopsis seed dormancy. Plant Cell Physiol. 53, 96-106. doi: 10.1093/pcp/pcr129
Lin, Y., Yang, L., Paul, M., Zu, Y., and Tang, Z. (2013). Ethylene promotes germination of Arabidopsis seed under salinity by decreasing reactive oxygen species: evidence for the involvement of nitric oxide simulated by sodium niroprusside. Plant Physiol. Biochem. 73, 211-218. doi: 10.1016/j.plaphy.2013.10.003

Lin, Y. C., Wang, J. J., Zu, Y. G., and Tang, Z. H. (2012). Ethylene antagonizes the inhibition of germination in Arabidopsis induced by salinity by modulating the concentration of hydrogen peroxide. Acta Physiol. Plant. 34, 1895-1904. doi: 10.1007/s11738-012-0989-8

Lin, Z., Zhong, S., and Grierson, D. (2009). Recent advances in ethylene research. J. Exp. Bot. 60, 3311-3336. doi: 10.1093/jxb/erp204

Linkies, A., and Leubner-Metzger, G. (2012). Beyond gibberellins and abscisic acid: how ethylene and jasmonates control seed germination. Plant Cell Rep. 31, 253270. doi: 10.1007/s00299-011-1180-1

Linkies, A., Muller, K., Morris, K., Tureckova, V., Wenk, M., Cadman, C. S., et al. (2009). Ethylene interacts with abscisic acid to regulate endosperm rupture during germination: a comparative approach using Lepidium sativum and Arabidopsis thaliana. Plant Cell 21, 3803-3822. doi: 10.1105/tpc.109.070201

Liu, Q., Zhou, G. Y., and Wen, C. K. (2004). Ethylene signal transduction in Arabidopsis. J. Plant Physiol. Mol. Biol. 30, 241-250.

Liu, Y., Ye, N., Liu, R., Chen, M., and Zhang, J. (2010). $\mathrm{H}_{2} \mathrm{O}_{2}$ mediates the regulation of ABA catabolism and GA biosynthesis in Arabidopsis seed dormancy and germination. J. Exp. Bot. 61, 2979-2990. doi: 10.1093/jxb/erq125

Longan, D. C., and Stewart, G. R. (1992). Germination of the seeds of parasitic angiosperms. Seed Sci. Res. 2, 179-190.

Lorenzo,O., Rodriguez, D., Nicolas, C., and Nicolas, G. (2000). "Characterization and expression of two protein kinase and an EIN3-like genes, which are regulated by ABA and GA3 in dormant Fagus sylvatica seeds," in Seed Biology: Advances and Applications, eds M. Black, K. J. Bradford, and J. Vazquez-Ramos (Wallingford: CAB International), 329-340.

Machabée, S., and Saini, H. S. (1991). Differences in requirement for endogenous ethylene during germination of dormant and non-dormant seeds of Chenopodium album L. J. Plant Physiol. 138, 97-101. doi: 10.1016/S01761617(11)80737-6

Martinez-Reina, G., Matilla, A. J., Martin-Remesal, C., Gallardo, M., and Munoz De Rueda, P. (1996). Biochemical properties of 1-aminocyclopropane-1-carboxylate $\mathrm{N}$-malonyl transferase activity from early growing embryonic axes of chickpea (Cicer arietinum L.) seeds. J. Exp. Bot. 47, 1771-1778. doi: 10.1093/jxb/47. 11.1771

Matilla, A. J. (1996). Polyamines and seed germination. Seed Sci. Res. 6, 81-93. doi: $10.1017 /$ S096025850000310X

Matilla, A. J. (2000). Ethylene in seed formation and germination. Seed Sci. Res. 10, 111-126. doi: 10.1017/S096025850000012X

Matilla, A. J., and Matilla-Vazquez, M. A. (2008). Involvement of ethylene in seed physiology. Plant Sci. 175, 87-97. doi: 10.1016/j.plantsci.2008.01.014

Mersmann, S., Bourdais, G., Rietz, S., and Robatzek, S. (2010). Ethylene signaling regulates accumulation of the FLS2 receptor and is required for the oxidative burst contributing to plant immunity. Plant Physiol. 154, 391-400. doi: 10.1104/pp.110.154567

Miransari, M., and Smith, D. L. (2014). Plant hormones and seed germination. Environ. Exp. Bot. 99, 110-121. doi: 10.1016/j.envexpbot.2013.11.005

Muday, G. K., Rahman, A., and Binder, B. M. (2012). Auxin and ethylene: collaborators or competitors? Trends Plant Sci. 17, 181-195. doi: 10.1016/j.tplants.2012.02.001

Müller, K., Linkies, A., Vreeburg, R. A. M., Fry, S. C., Krieger-Liszkay, A., and Leubner-Metzger, G. (2009). In vivo cell wall loosening by hydroxyl radicals during cress (Lepidium sativum L.) seed germination and elongation growth. Plant Physiol. 150, 1855-1865. doi: 10.1104/pp.109. 139204

Nambara, E., Okamoto, M., Tatematsu, K., Yano, R., Seo, M., and Kamiya, Y. (2010). Abscisic acid and the control of seed dormancy and germination. Seed Sci. Res. 20, 55-67. doi: 10.1017/S0960258510000012

Narsai, R., Law, S. R., Carrie, C., Xu, L., and Whelan, J. (2011). In depth temporal transcriptome profiling reveals a crucial developmental switch with roles for RNA processing and organelle metabolism that are essential for germination in Arabidopsis thaliana. Plant Physiol. 157, 1342-1362. doi: 10.1104/pp.111.183129

Ne'eman, G., Henig-Sever, N., and Eshel, A. (1999). Regulation of the germination of Rhus coriaria, a post-fire pioneer, by heat, ash, $\mathrm{pH}$, waterpotential and ethylene. Physiol. Plant. 106, 47-52. doi: 10.1034/j.1399-3054.1999.106107.x 
Negm, F. B., and Smith, O. E. (1978). Effects of ethylene and carbon dioxide on the germination of osmotically inhibited lettuce seeds. Plant Physiol. 49, 869-872. doi: 10.1104/pp.49.6.869

Negm, F. B., Smith, O. E., and Kumamoto, J. (1973). The role of phytochrome in an interaction with ethylene and carbon dioxide in overcoming lettuce seed thermodormancy. Plant Physiol. 51, 1089-1094. doi: 10.1104/pp.51.6.1089

Nemhauser, J. L., Hong, F., and Chory, J. (2006). Different plant hormones regulate similar processes through largely nonoverlapping transcriptional responses. Cell 126, 467-475. doi: 10.1016/j.cell.2006.05.050

Nonogaki, H., Bassel, G. W., and Bewley, J. D. (2010). Germination - Still a mystery. Plant Sci. 179, 574-581. doi: 10.1016/j.plantsci.2010.02.010

Ogawa, M., Hanada, A., Yamauchi, Y., Kuwahara, A., Kamiya, Y., and Yamaguchi, S. (2003). Gibberellin biosynthesis and response during Arabidopsis seed germination. Plant Cell 15, 1591-1604. doi: 10.1105/tpc.011650

Olatoye, S. T., and Hall, M. A. (1973). "Interaction of ethylene and light on dormant weed seeds," in Seed Ecology, ed. W. Heydecker (London: Butterworths), 233-240.

Oracz, K., El-Maarouf-Bouteau, H., Bogatek, R., Corbineau, F., and Bailly, C. (2008). Release of sunflower seed dormancy by cyanide: cross-talk with ethylene signaling pathway. J. Exp. Bot. 59, 2241-2251. doi: 10.1093/jxb/ern089

Oracz, K., El-Maarouf-Bouteau, H., Farrant, J. M., Cooper, K., Belghazi, M., Job, C., et al. (2007). ROS production and protein oxidation as a novel mechanism for seed dormancy alleviation. Plant J. 50, 452-465. doi: 10.1111/j.1365313X.2007.03063.x

Oracz, K., El-Maarouf-Bouteau, H., Kranner, I., Bogatek, R., Corbineau, F., and Bailly, C. (2009). The mechanisms involved in seed dormancy alleviation by hydrogen cyanide unravel the role of reactive oxygen species as key factors of cellular signaling during germination. Plant Physiol. 150, 494-505. doi: 10.1104/pp.109.138107

Ouaked, F., Rozhon, W., Lecourieux, D., and Hirt, H. (2003). A MAPK pathway mediates ethylene signaling in plants. EMBO J. 22, 1282-1288. doi: 10.1093/emboj/cdg131

Overmyer, K., Brosche, M., and Kangasjarvi, J. (2003). Reactive oxygen species and hormonal control of cell death. Trends Plant Sci. 8, 335-342. doi: 10.1016/S13601385(03)00135-3

Penfield, S., Li, Y., Gilday, A. D., Graham, S., and Graham, I. A. (2006). Arabidopsis ABA INSENSITIVE4 regulates lipid mobilization in the embryo and reveals repression of seed germination by the endosperm. Plant Cell 18, 1887-1899. doi: 10.1105/tpc.106.041277

Perino, C., Simond-Côte, E., and Côme, D. (1984). Effets du cyanure de potassium et de l'acide salicylhydroxamique sur la levée de dormance et l'activité respiratoire des embryons de Pommier (Pirus malus L.). C. R. Acad. Sci. Paris III 299, 249-251.

Petruzzelli, L., Coraggio, I., and Leubner-Metzger, G. (2000). Ethylene promotes ethylene biosynthesis during pea seed germination by positive feedback regulation of 1-amonocyclopropane-1-carboxylic acid oxidase. Planta 211, 144-149. doi: $10.1007 / \mathrm{s} 004250000274$

Petruzzelli, L., Sturaro, M., Mainieri, D., and Leubner-Metzger, G. (2003). Calcium requirement for ethylene-dependent responses involving 1-aminocyclopropane1 -carboxylic acid oxidase in radicle tissues of germinated pea seeds. Plant Cell Environ. 26, 661-671. doi: 10.1046/j.1365-3040.2003.01001.x

Pirrello, J., Jaimes-Miranda, F., Sanchez-Ballesta, M. T., Tournier, B., Khalil-Ahmad, Q., Regad, F., et al. (2006). Sl-ERF2, a tomato ethylene response factor involved in ethylene response and seed germination. Plant Cell Physiol. 47, 1195-1205. doi: $10.1093 / \mathrm{pcp} / \mathrm{pcj} 084$

Piskurewicz, U., Jikumaru, Y., Kinoshita, N., Nambara, E., Kamiya, Y., and Lopez-Molina, L. (2008). The gibberellic acid signaling repressor RGL2 inhibits Arabidopsis seed germination by stimulating abscisic acid synthesis and ABI5 activity. Plant Cell 20, 2729-2745. doi: 10.1105/tpc.108.061515

Prusinski, J., and Khan, A. A. (1990). Relationship of ethylene production to stress alleviation in seeds of lettuce cultivars. J. Am. Soc. Hort. Sci. 115, 294-298.

Puga-Hermida, M. I., Gallardo, M., Rodroguez-Gacio, M. D., and Matilla, A. J. (2003). The heterogeneity of turnip-tops (Brassica rapa) seeds inside the silique affects germination, the activity of the final step of the ethylene pathway, and abscisic acid and polyamine content. Funct. Plant Biol. 30, 767-775. doi: 10.1071/FP03053

Qiao, H., Chang, K. N., Yazaki, J., and Ecker, J. R. (2009). Interplay between ethylene, ETP1/ETP2 F-box proteins, and degradation of EIN2 triggers ethylene responses in Arabidopsis. Genes Dev. 23, 512-521. doi: 10.1101/gad.1765709
Qiao, H, Shen, Z., Huand, S.-S. C., Schmitz, R. J., Urich, M. A., Briggs, S. P., et al. (2012). Processing and subcellular trafficking of ER-tethered EIN2 control response to ethylene gas. Science 338, 390-393. doi: 10.1126/science.1225974

Rajjou, L., Duval, M., Gallardo, K., Catusse, J., Bally, J., Job, C., et al. (2012). Seed germination and vigor. Annu. Rev. Plant Biol. 63, 507-533. doi: 10.1146/annurevarplant-042811-105550

Rao, V. S., Sankhla, N., and Khan, A. A. (1975). Additive and synergistic effects of kinetin and ethrel on germination, thermodormancy, and polyribosome formation in lettuce seeds. Plant Physiol. 56, 263-266. doi: 10.1104/pp.56.2.263

Ribeiro, D. M., and Barros, R. S. (2006). Sensitivity to ethylene as a major component in the germination of seeds of Stylosanthes humilis. Seed Sci. Res. 16, 37-45. doi: 10.1079/SSR2005233

Rzewuski, G., and Sauter, M. (2008). Ethylene biosynthesis and signaling in rice. Plant Sci. 175, 32-42. doi: 10.1016/j.plantsci.2008.01.012

Saini, H. S., Consolacion, E. D., Bassi, P. K., and Spencer, M. S. (1986). Requirement for ethylene synthesis and action during relief of thermoinhibition of lettuce seed germination by combinations of gibberellic acid, kinetin, and carbon dioxide. Plant Physiol. 81, 950-953. doi: 10.1104/pp.81.4.950

Samimy, C., and Khan, A. A. (1983). Secondary dormancy, growth-regulator effects, and embryo growth potential in curly dock (Rumex crispus) seeds. Weed Sci. 31, 153-158.

Samimy, C., and Taylor, A. G. (1983). Influence of seed quality on ethylene production of germinating snap bean seeds. J. Am. Soc. Hort. Sci. 108, 767-769.

Satoh, S., and Esashi, Y. (1983). Ethylene production, 1-aminocyclopropane-1carboxylic acid content and its conversion to ethylene in axial segments of dormant and nondormant cocklebur seeds. Plant Cell Physiol. 24, 883-887.

Satoh, S., Takeda, Y., and Esashi, Y. (1984). Dormancy and impotency of cocklebur seeds. IX. Changes in ACC-ethylene conversion activity and ACC content of dormant and non-dormant seeds during soaking. J. Exp. Bot. 35, 1515-1524. doi: 10.1093/jxb/35.10.1515

Schönbeck, M. W., and Egley, G. H. (1981). Phase-sequence of redroot pigweed seed germination responses to ethylene and other stimuli. Plant Physiol. 68, 175-179. doi: $10.1104 /$ pp.68.1.175

Schwechheimer, C. (2008). Understanding gibberellic acid signaling-are we there yet? Curr. Opin. Plant Biol. 11, 9-15. doi: 10.1016/j.pbi.2007.10.011

Sewelam, N., Kazan, K., Thomas-Hall, S. R., Kidd, B. N., Manners, J. M., and Schenk, P. M. (2013). Ethylene response factor 6 is a regulator of reactive oxygen species signaling in Arabidopsis. PLoS ONE 8:e70289. doi: 10.1371/journal.pone.0070289

Silva, P. O., Medina, E. F., Barros, R. S., and Ribeiro, D. M. (2014). Germination of salt-stressed seeds as related to ethylene biosynthesis ability in three Stylosanthes species. J. Plant Physiol. 171, 14-22. doi: 10.1016/j.jplph.2013. 09.004

Sinska, I. (1989). Interaction of ethephon with cytokinin and gibberellin during the removal of apple seed dormancy and germination of embryos. Plant Sci. 64, 39-44. doi: 10.1016/0168-9452(89) 90149-0

Sinska, I., and Gladon, R. (1984). Ethylene and the removal of embryonal apple seed dormancy. HortScience 19, 73-75.

Sinska, I., and Gladon, R. (1989). Effects of inhibitors of synthesis and action of ethylene on apple seed stratification and embryo germination. Acta Physiol. Plant. 11, 307-316.

Sinska, I., and Lewandowska, U. (1991). Polyamines and ethylene in the removal of embryonal dormancy in apple seeds. Physiol. Plant. 81, 59-64. doi: 10.1111/j.1399-3054.1991.tb01713.x

Siriwitayawan, G., Geneve, R. L., and Downie, A. B. (2003). Seed germination of ethylene perception mutants of tomato and Arabidopsis. Seed Sci. Res. 13, 303-314. doi: 10.1079/SSR2003147

Speer, H. L., Hsiao, A. I., and Vidaver, W. (1974). Effects of germination promoting substances given in conjunction with red light on the phytochrome-mediated germination of dormant lettuce seeds (Lactuca sativa L.). Plant Physiol. 54, 852854. doi: $10.1104 /$ pp.54.6.852

Steber, C. M. (2007). "De-repression of seed germination by GA signaling," in Annual Plant Reviews, Vol. 27, Seed Development, Dormancy and Germination, eds K. Bradford and H. Nonogaki (Oxford: Blackwell Publishing Ltd), 248-263. doi: 10.1002/9780470988848.ch10

Stepanova, A. N., and Alonso, J. M. (2009). Ethylene signaling and response: where different regulatory modules meet. Curr. Opin. Plant Biol. 12, 548-555. doi: 10.1016/j.pbi.2009.07.009 
Subbiah, V., and Reddy, K. J. (2010). Interactions between ethylene, abscisisc acid and cytokinin during germination and seedling establishment in Arabidopsis. J. Biosci. 35, 451-458. doi: 10.1007/s12038-010-0050-2

Sun, T. P., and Gubler, F. (2004). Molecular mechanism of gibberellin in plants. Annu. Rev. Plant Biol. 7, 847-859. doi: 10.1146/annurev.arplant.55.031903.141753

Takayanagi, K., and Harrington, J. F. (1971). Enhancement of germination rate of aged seeds by ethylene. Plant Physiol. 47, 521-524. doi: 10.1104/pp.47.4.521

Taylorson, R. B. (1979). Response of weed seeds to ethylene and related hydrocarbons. Weed Sci. 27, 7-10.

Thomas, T. H., Palevitch, D., Biddington, N. L., and Austin, R. B. (1975). Growth regulators and the phytochrome-mediated dormancy of celery seeds. Physiol. Plant. 35, 101-106. doi: 10.1111/j.1399-3054.1975. tb03876.x

Toorop, P. E., van Aelst, A. C., and Hilhorst, H. W. (2000). The second step of the biphasic endosperm cap weakening that mediates tomato (Lycopersicon esculentum) seed germination is under control of ABA. J. Exp. Bot. 51, 371-379. doi 10.1093/jexbot/51.349.1371

Tyler, L., Thomas, S. G., Hu, J., Dill, A., Alonso, J. M., Ecker, J. R., et al. (2004). DELLA proteins and gibberellin-regulated seed germination and floral development in Arabidopsis. Plant Physiol. 135, 1008-1019. doi: 10.1104/pp.104. 039578

Wang, B., Zhang, J., Xia, X., and Zhang, W. H. (2011). Ameliorative effect of brassinosteroid and ethylene on germination of cucumber seeds in the presence of sodium chloride. Plant Growth Regul. 65, 407-413. doi: 10.1007/s10725-0119595-9

Wang, K. L. C., Li, H., and Ecker, J. R. (2002). Ethylene biosynthesis and signaling networks. Plant Cell 14(Suppl. ), S131-S151.

Wang, N. N., Shih, M. C., and Li, N. (2005). The GUS reporter-aided analysis of the promoter activities of Arabidopsis ACC synthase genes AtACS4, AtACS5, and AtACS7 induced by hormones and stresses. J. Exp. Bot. 56, 909-920. doi: 10.1093/jxb/eri083

Wang, W., Esch, J. J., Shiu, S.-H., Agula, H., Binder, B. M., Chang, C., et al. (2006). Identification of important regions for ethylene binding and signaling in the transmembrane domain of the ETR1 ethylene receptor of Arabidopsis. Plant Cell 18, 3429-3442. doi: 10.1105/tpc.106.044537

Wang, Y., Liu, C., Li, K., Sun, F., Hu, H., Li, X., et al. (2007). Arabidopsis EIN2 modulates stress response through abscisic acid response pathway. Plant Mol. Biol. 64, 633-644. doi: 10.1007/s11103-007-9182-7

Weiss, D., and Ori, N. (2007). Mechanisms of cross talk between gibberellin and other hormones. Plant Physiol. 144, 1240-1246. doi: 10.1104/pp.107. 100370

Weitbrecht, K., Müller, K., and Leubner-Metzger, G. (2011). First of the mark: early seed germination. J. Exp. Bot. 62, 3289-3309. doi: 10.1093/jxb/err030
Wilson, R. L., Kim, H., Bakshi, A., and Binder, B. M. (2014a). The ethylene receptors ETHYLENE RESPONSE1 and ETHYLENE RESPONES2 have contrasting roles in seed germination of Arabidopsis during salt stress. Plant Physiol. 165, 1353-1366. doi: 10.1104/pp.114.241695

Wilson, R. L., Bakshi, A., and Binder, B. M. (2014b). Loss of the ETR1 ethylene receptor reduces the inhibitory effect of far-red light and darkness on seed germination of Arabidopsis thaliana. Front. Plant Sci. 5:433. doi: 10.3389/fpls. 2014.00433

Yamagami, T., Tsuchisaka, A., Yamada, K., Haddon, W. F., Harden, L. A., and Theologis, A. (2003). Biochemical diversity among the 1aminocyclopropane-1-carboxylate synthase isozymes encoded by the Arabidopsis gene family. J. Biol. Chem. 278, 49102-49112. doi: 10.1074/jbc.M308 297200

Yang, S. F., and Hoffman, N. E. (1984). Ethylene biosynthesis and its regulation in higher plants. Annu. Rev. Plant Physiol. Plant Mol. Biol. 35, 155-189. doi: 10.1146/annurev.arplant.35.1.155

Yoo, S. D., Cho, Y. H., and Sheen, J. (2009). Emerging connections in the ethylene signaling network. Trends Plant Sci. 14, 270-279. doi: 10.1016/j.tplants.2009.02.007

Yoo, S. D., Cho, Y. H., Tena, G., Xiong, Y., and Sheen, J. (2008). Dual control of nuclear EIN3 by bifurcate MAPK cascades in $\mathrm{C}_{2} \mathrm{H}_{4}$ signalling. Nature 451, 789-795. doi: 10.1038/nature06543

Zapata, H., P. J., Serrano, M., Pretel, M. T., Amoros, A., and Botella, M. A. (2003). Changes in ethylene evolution and polyamine profiles of seedlings of nine cultivars of Lactuca sativa L. in response to salt stress during germination. Plant Sci. 164, 557-563. doi: 10.1016/S0168-9452(03)00005-0

Conflict of Interest Statement: The authors declare that the research was conducted in the absence of any commercial or financial relationships that could be construed as a potential conflict of interest.

Received: 14 August 2014; accepted: 22 September 2014; published online: 10 October 2014.

Citation: Corbineau F, Xia Q, Bailly C and El-Maarouf-Bouteau H (2014) Ethylene, a key factor in the regulation of seed dormancy. Front. Plant Sci. 5:539. doi: 10.3389/fpls.2014.00539

This article was submitted to Plant Physiology, a section of the journal Frontiers in Plant Science.

Copyright (c) 2014 Corbineau, Xia, Bailly and El-Maarouf-Bouteau. This is an openaccess article distributed under the terms of the Creative Commons Attribution License (CC BY). The use, distribution or reproduction in other forums is permitted, provided the original author(s) or licensor are credited and that the original publication in this journal is cited, in accordance with accepted academic practice. No use, distribution or reproduction is permitted which does not comply with these terms. 